\title{
I I
}

\section{Prostorska analiza prebivalstva in živinoreje na Primorskem na podlagi franciscejskega katastra (1827)}

\author{
Nataša Kolega \\ Univerza na Primorskem \\ Fakulteta za humanistične študije \\ Titov $\operatorname{trg}$ 5, 6000 Koper \\ natasa.kolega@fhs.upr.si
}

\section{Uvod}

Franciscejski kataster je bogat in še neizčrpan vir podatkov o življenju na območju Habsburške monarhije v 19. stoletju. S pomočjo geografskih informacijskih sistemov (GIS) smo v raziskavi, predstavljeni v nadaljevanju, poskušali na podlagi franciscejskega katastra (v nadaljevanju FK) analizirati in rekonstruirati nekatere vidike demografskega in ekonomskega stanja na Primorskem v prvi polovici 19. stoletja. Analiza je ozemeljsko obsežna in predstavlja predvsem osnovo za nadaljnje raziskovanje na področju zgodovine ter izvedbo podrobnejših geografskih analiz na manjših območjih. Prav tako pa bi bilo v podrobnejših analizah potrebno upoštevati tudi druge ekonomske, demografske in ozemeljske značilnosti. Osnovni namen raziskave je bil analizirati nekatere osnovne demografske in ekonomske podatke iz cenilnih operatov FK, ki omogočajo kvantitativno analizo.

Prikaz rezultatov raziskave je sestavljen iz več delov: v začetnem delu je natančneje predstavljen FK in njegov nastanek, temu sledi analiza ozemeljskih značilnosti območja. Osrednji del prispevka je namenjen analizi osnovnih demografskih značilnosti ter prisotnosti posameznih vrst živine v obravnavanem prostoru. V sklepnem delu skušamo opredeliti območja, kjer prevladujejo skupne poteze.

Franciscejski kataster je kataster, ki se ga na območju Slovenije najpogosteje uporablja za študije spreminjanja rabe tal in pokrajine $\mathrm{v}$ preteklosti. Je tudi najcelovitejši kataster oz. popis iz tistega časa in, kar je pomembno, 
razmeroma lahko dostopen, saj je $\mathrm{v}$ veliki meri digitaliziran in dostopen preko spletnih pregledovalnikov raznih arhivov. Vendar FK ni prvi kataster za slovensko ozemlje, pred njim jih je bilo še nekaj. Začetki zemljiškega katastra v Habsburški monarhiji, podobni današnji obliki, segajo v obdobje po letu 1714, ko je nastal milanski kataster (Čeh 2002), ki je bil prvi enovit sistem obdavčitve zemljišča v Evropi. Vsebuje tako grafični kot opisni del, osnovna prostorska enota pa so katastrske občine. (Ferlan 2005; Feucht 2008). Leta 1747 je cesarica Marija Terezija z zakonom odredila popis vseh zemljišč v cesarstvu, iz česar je nastal terezijanski kataster, ki je bil pravzaprav nadaljevanje milanskega katastra, le da ni vseboval grafičnih prilog. Zaradi ugotovljenih pomanjkljivosti skozi dolgoletno uporabo terezijanskega katastra in hkratne izboljšane organiziranosti državne uprave je cesar Jožef II. po smrti Marije Terezije naročil posodobitev evidence zemljišč. Nastal je jožefinski kataster, ki je vseboval tudi dokaj natančen grafični del (Ribnikar 1982; Triglav 2009; Verdeber 2013).

Leta 1806 je cesar Franc I. izdal ukaz o vpeljavi skupnega, enako delujočega in stabilnega katastra za celotno državo. Dela so se pričela, vendar zaradi vojn $\mathrm{z}$ Napoleonom tudi prekinila do leta 1817 . Konec istega leta je bil sprejet zakon o zemljiškem davku. Osnovne enote za izdelavo franciscejskega katastra so bile katastrske občine, izoblikovane ob izdelavi jožefinskega katastrskega operata, katastrska izmera pa se je morala navezovati na trigonometrično mrežo (Ferlan 2005; Triglav 2009; Verdeber 2013).

Izmera zemljišč je bila je za takratne razmere izredno natančna, opravili pa so jo za to izšolani geometri. Najprej so morali določiti geodetsko osnovo za merjenje. Po določitvi koordinatnega sistema za vso Avstrijo in po določitvi koordinatnih točk, ki so bile za slovensko ozemlje na Schöcklu pri Gradcu in na Krimu pri Ljubljani, je bila izdelana podlaga za izvedbo triangulacije in za katastrsko izmero. Originalne katastrske mape in indikacijske skice so bile izdelane v merilu $1: 2880$; za merjenje v težko dostopnih krajih se je lahko uporabljalo merilo $1: 5760$, za merjenje $v$ mestih pa tudi merilo $1: 1440$ ali celo $1: 720$ (Triglav 2009).

Najprej so opravili popis meje katastrske občine, sledila pa je natančna izmera v njenem okviru. Območje izmere so razdelili na ledine in grupe. Hkrati z izmero sta se vodila terenska skica in dnevnik izmere. Meritve so izvedli z naslednjimi inštrumenti: merilna miza, terenska busola, libela, varovalna magnetna igla v posebnem ohišju, diopter $\mathrm{z}$ ravnilom, grezilo, deset setnjev dolga členasta merska veriga, merske zastavice, merske tarče in komplet šestil (Mlakar 1986, Ferlan 2005, Verdeber 2013). 
Franciscejski kataster sestavljata dva dela: grafični in opisni. Grafični del vsebuje originalno katastrsko mapo, indikacijsko skico, mapno kopijo in rektifikacijsko mapo. Originalna katastrska mapa je bila izdelana kot avtentičen prikaz stanja vseh zemljišč v katastrski občini v merilu $1: 2880$. $\mathrm{Na}$ njej je prikazana raba tal po vnaprej določenih barvah in kategorijah. Posebej so označene tudi stavbne in nestavbne parcele ter razni napisi, vse s strogo določenimi barvami in znaki. Originalna katastrska mapa vsebuje naslednje podatke: številka zemljiške ali stavbne parcele, naris stavbe ali gradbenega objekta, zapis imena naselja, zapis imena ledine in zapis topografskega znaka za določeno kulturo (rabo tal). Indikacijska skica je zelo podobna originalni katastrski mapi, le da vsebuje še podatke o lastniku in koristniku zemljišča, namenjena pa je komisijskemu preverjanju točnosti izmere na terenu. Mapne kopije so litografsko odlite kopije originalne katastrske mape, namenjene konkretni uporabi za upravne in druge potrebe, da se je original ohranjal. Nanje so tudi vrisovali kasnejše popravke in spremembe (Ribnikar 1982).

Rektifikacijska mapa je bila izdelana v začetku 40. let 19. stoletja, torej približno 20 let po nastanku originalne mape, in predstavlja neobarvano mapno kopijo $\mathrm{z}$ izrisanimi vsemi popravki, delitvami in spremembami, ki so se v tem času zgodile. Popravki so bili vnešeni $\mathrm{z}$ rdečo barvo, nove številke parcel, kjer je bilo to potrebno, pa dodane kot ulomek k originalni številki. Rektifikacijska mapa je skupaj z originalno mapo služila kot osnova za izdelavo kasnejših reambulančnih katastrskih operatov (Ribnikar 1982).

Opisni del franciscejskega katastra oz. operat sestavljajo: zapisnik zemljiških parcel, zapisnik stavbnih parcel, izkaz površine zemljišč po katastrskih kulturah, abecedni seznam zemljiških posestnikov, popis mej katastrske občine, seznam neznanih lastnikov, zapisnik o izračunavanju površine zemljišč in pismena dokazila o imenovanju. Franciscejski katastrski operat za današnje slovensko ozemlje ne vsebuje zadnjih treh sestavnih delov, pač pa so mu priključeni t. i. cenilni operati (izračuni davkov glede na velikost in kvaliteto oz. donos zemljišč; Arhiv Republike Slovenije 2017). V uvodnem delu cenilnega operata so med drugim podani podatki o številu in sestavi prebivalstva ter živine, ki so podlaga za to študijo.

Zapisnik zemljiških parcel vsebuje podatke o parceli, lastniku, rabi tal, kakovosti parcele, vrednosti ipd. Zapisnik stavbnih parcel obsega podatke o zgradbah, kot so tip zgradbe in njene značilnosti. Obrazec za izkaz površine zemljišč po kulturah prikazuje seštevek površin parcel glede na kategorije kultur. Obrazec za abecedni seznam zemljiških posestnikov katastr- 
ske občine je namenjen pregledu lastnikov zemljišč in evidentiranju vseh parcel, ki jih je posedoval posamezen lastnik. Popis mej katastrske občine vsebuje podatke o razsežnosti občine $\mathrm{v}$ dolžino in širino, položaj katastrske občine v okviru okrajne gosposke ter opis meje s postavljenimi mejniki (Ribnikar 1982).

Triangulacija in katastrska izmera sta bili najprej opravljeni $\mathrm{v}$ Slovenskem Primorju in Istri v letih 1817-1825, na Štajerskem v letih 18191825, na Kranjskem v letih 1822-1826 in na Koroškem v letih 1825-1828; ozemlje Prekmurja ni bilo zajeto v katastrsko izmero v času vladanja Franca I. (Ribnikar 1982).

Katastrski operati so za zgodovinopisje in zlasti za gospodarsko zgodovino bogat vir informacij, saj vsebujejo številne podatke o gospodarskem stanju v času njihovega nastanka, in sicer za mesta, trge in vasi, obrtništvo in manufakture, poleg tega pa podajajo celovite podatke o lastništvu zemljišč, iz česar je mogoče razbrati razslojenost posestnikov. Prav tako nudijo vpogled $\mathrm{v}$ agrarno gospodarstvo, način obdelave in rabe zemlje, uvajanje novih agrarnih kultur, stanje živinoreje, izkoriščanje servitutnih pravic, določanje cen kmetijskih pridelkov, uveljavljanje enotne vrednosti denarja in enotnih dolžinskih ter površinskih mer. Iz njih je mogoče razbrati informacije o oblikovanju tržnih središč s posebnim ozirom na povezovanje urbanih naselij s podeželjem, stanju prometnih povezav, kmečki trgovini, o ledinskih in krajevnih imenih in še bi lahko naštevali. Katastri so pomembni tudi za zgodovino uprave. Posebno zgodovinsko in likovno vrednost pa predstavlja grafični del franciscejskega katastrskega operata. Originalne katastrske mape in indikacijske skice nam dajejo vizualno podobo narisa kulturne krajine s posebnim ozirom na upodobitev zemljiških in stavbnih parcel. Grafični narisi v odmerjenem prostoru prikazujejo stanovanjska in gospodarska poslopja, objekte sakralnega značaja, vodotoke, ceste, poti, razne naravne in druge posebnosti, zajete $\mathrm{v}$ krajini. Katastrska mapa je zgodovinski dokument zajetja agrarnega, geografskega in urbanističnega trenutka pokrajine (Ribnikar 1982).

Podatki iz cenilnih operatov franciscejskega katastra, ki so podlaga za to raziskavo, so bili pridobljeni v treh arhivih: ozemeljsko najobsežnejši del v Državnem arhivu v Trstu, del v Arhivu Republike Slovenije v Ljubljani, del pa tudi v Državnem arhivu v Gorici.'

1 Nabor podatkov iz arhivskega gradiva, ki tvori podlago za to študijo, je izvedla Petra Kavrečič s sodelavci v okviru projekta Integrirana kmečka ekonomija na Slovenskem. 


\section{Metodologija}

\subsection{Vzpostavitev baze podatkov}

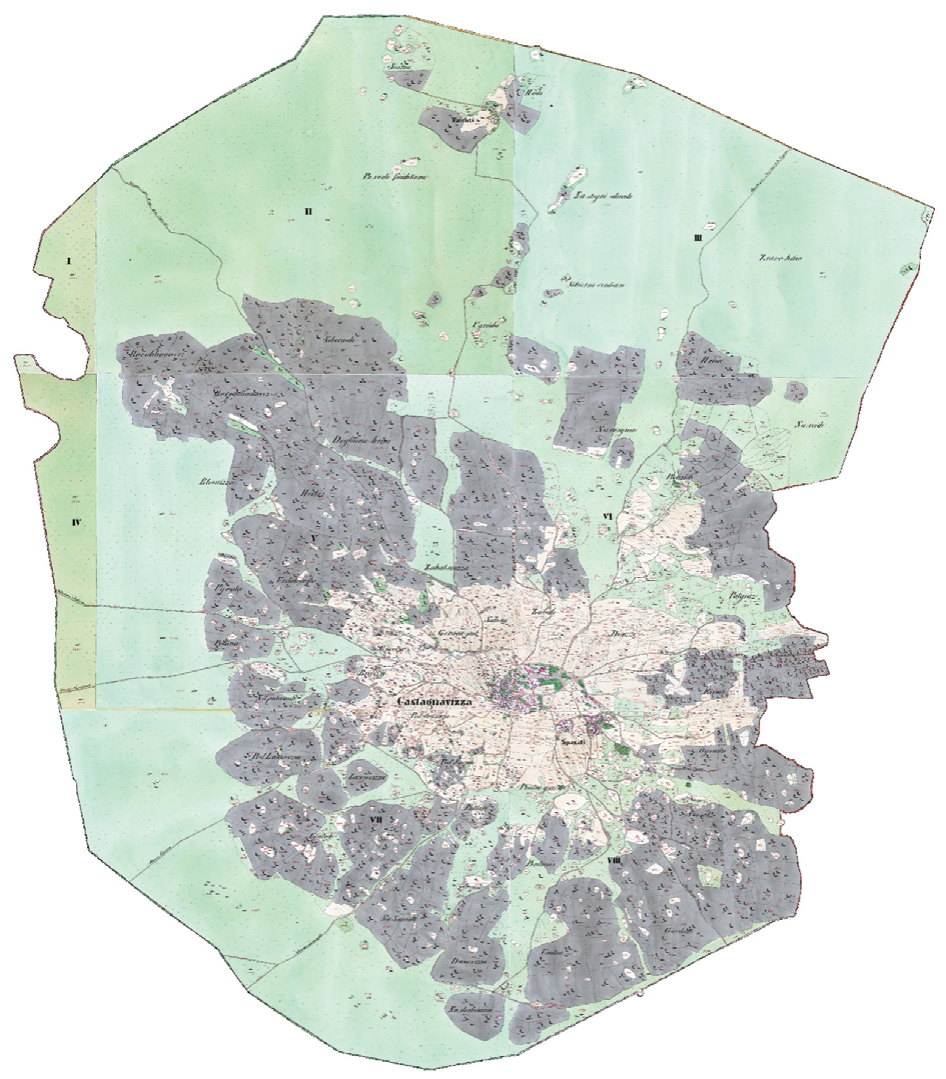

Slika II.I: Primer združenih in obrezanih katastrskih map franciscejskega katastra za Kostanjevico

Vzpostavitev prostorske baze podatkov je obsegala več različnih, ločenih korakov. Za prostorsko bazo podatkov je značilno, da so podatki v njej organizirani na podlagi svoje lokacije $\mathrm{v}$ prostoru, kar omogoča njihovo nadaljnjo prostorsko analizo. Najprej je bilo potrebno od pristojnih arhivov (Državnega arhiva v Trstu, Državnega arhiva v Gorici in Arhiva Republike Slovenije v Ljubljani) pridobiti preslikane originalne katastrske mape oz. $\mathrm{v}$ nekaterih primerih preslikane mapne kopije franciscejskega katastra. Pridobljene podlage je bilo v prvi fazi potrebno urediti po regijah oz. ob- 
močjih, saj vsi trije arhivi ne uporabljajo enakega načina razvrščanja in poimenovanja.

Osnovna prostorska enota za izdelavo franciscejskega katastra in prav tako za našo raziskavo so bile katastrske občine (v nadaljevanju k. o.). Zaradi velikosti k. o. in zadanega merila ( $1: 2880)$ celotne k. o. niso mogli narisati na en list, zato so jih razrezali na več listov, katerih število je večinoma med štiri in deset. Iz skoraj nepregledne gmote preslikanih podlag, pridobljenih iz arhivov, je bilo potrebno poiskati tiste, ki sestavljajo isto k. o., in jih sestaviti v enovito sliko, ki je obsegala celotno k. o., ter obrezati ozadje - list papirja.

\subsection{Georeferenciranje katastrskih map franciscejskega katastra, vnos in sestava baze podatkov}

Sledil je najzahtevnejši in časovno najobsežnejši korak celotne raziskave, georeferenciranje podlag, ki si tudi na tem mestu zasluži nekoliko več pozornosti. Georeferenciranje, preprosteje povedano, pomeni umeščanje $\mathrm{v}$ prostor. To je digitalni postopek, pri katerem preslikane karte umeščamo v prostor na osnovi podlage, ki je že umeščena v prostor. Gre za običajen postopek, ki se ga uporablja za razne preslikane ali starejše karte. Umestitev v prostor izvajamo s pomočjo kontrolnih točk. Kontrolne točke so prepoznavne točke, prisotne na obeh kartah, kot so na primer ceste, mostovi, hiše, meje, rti, otoki ipd. Neko točko, ki jo prepoznamo na obeh kartah, s pomočjo kontrolnih točk povežemo. To preprosto pomeni, da neko prepoznano točko, ki se pojavi na obeh kartah, najprej označimo na še negeoreferencirani karti, nato pa še na že georeferencirani podlagi. Več kot je kontrolnih točk in bolj enakomerno kot so razporejene, boljša je pretvorba. Rezultat je, da se karta ponekod raztegne, ponekod skrči, skratka, deformira glede na obstoječo podlago, ki je v prostor že umeščena. Za dosego zadovoljivega rezultata je za umestitev v prostor ene podlage, $v$ našem primeru ene k. o., potrebnih med 30 in 40 enakomerno razporejenih kontrolnih točk.

Ker so katastrske mape franciscejskega katastra razmeroma stare in se je pokrajina od takrat do danes precej spremenila, je georeferenciranje $\mathrm{v}$ takšnem primeru lahko zelo zahtevno in dolgotrajno. Delno si je mogoče pomagati z digitaliziranimi mejami današnjih k. o., ki slonijo na franciscejskem katastru, vendar so te meje v nekaterih primerih spreminjale svoj potek, posamezne katastrske občine so se razdelile v več samostojnih, v nekaterih primerih pa so se deli k. o. priključili k sosednjim k. o. 
Zato uporaba mej današnjih k. o. omogoča zgolj orientacijo, ne pa dejansko umeščanja $\mathrm{v}$ prostor. Za umeščanje $\mathrm{v}$ prostor so se kot že umeščena podlaga najpogosteje uporabljali Digitalna topografska karta Slovenije v merilu $1: 50000$ in razni digitalni ortofoto posnetki. Ko je bila katastrska mapa k. o. iz franciscejskega katastra dokončno umeščena v prostor, se je glede na njene meje izdelal/popravil še sloj mej k. o. Ko so bile vse katastrske mape $\mathrm{FK}$ umeščene $\mathrm{v}$ prostor, smo na tak način posledično dobili še nov sloj mej k. o. v času franciscejskega katastra, ki je bil pravzaprav osnova za nadaljnjo raziskavo.

Za pridobitev demografskih in ekonomskih podatkov iz cenilnih operatov je bil ponovno potreben obisk arhivov oz. pregledovanje digitaliziranih opisnih delov (cenilnih operatov) preko spleta. Zbrani kvantitativni podatki o prebivalstvu in živini se nahajajo $v$ uvodnem delu cenilnih operatov. Podatke smo vnesli v podatkovno bazo in jih vezali na sloj k. $\mathrm{o}$. iz časa franciscejskega katastra. Prostorska baza podatkov je tako na koncu obsegala naslednje podatke oz. prostorske sloje: rastrske podlage k. o. iz FK, katastrske občine iz FK, kvantitativne demografske in ekonomske podatke iz cenilnih operatov, vezane na $\mathrm{k}$. $\mathrm{o}$.

Vendar vzpostavitev prostorske baze podatkov ni potekala brez težav. Največ jih je bilo z georeferenciranjem, še prej pa s sestavljanjem k. o. iz FK. Meje posameznih k. o. se v nekaterih primerih niso ujemale, ponekod so se vmes pojavljale tudi praznine, kar je povzročalo težave pri izdelavi sloja k. o. iz FK. Posebna težava so bili tudi manjkajoči podatki. Nekateri listi ali katastrske mape za celotne k. o. so se tekom časa izgubili, zato so nekatera območja brez podatkov. Še več podatkov manjka pri demografskih in ekonomskih informacijah iz cenilnih operatov. Ponekod so se izgubili celotni operati, ponekod le posamezni listi. Posebno težavo pa predstavlja dejstvo, da kljub razmeroma natančnim navodilom pri sami izdelavi FK (Ribnikar 1982) niso bili povsod popisani isti podatki ali ponekod določenih podatkov preprosto niso popisali. Vrste živine so se ponekod združevale, drugod so bile popisane ločeno, na primer, ponekod se pojavlja kategorija število ovc in koz skupaj, drugod so ovce in koze navedene posebej. Zaradi tega je bilo potrebno kategorije za nadaljnjo analizo poenotiti, kar $\mathrm{v}$ večini primerov pomeni združevanje $\mathrm{v}$ širše skupine (na primer, kjer so bile ovce in koze navedene posebej, jih sešteti v kategorijo ovce in koze skupaj, da so bili podatki primerljivi z drugimi k. o). S tako vzpostavljeno in poenoteno prostorsko bazo podatkov smo lahko pričeli s prostorsko analizo. 


\subsection{Analiza podatkov}

Analizirano območje obsega Primorsko, to je Posočje, Goriško, Vipavsko dolino, Kras, Brkine in severno Istro. Površina celotnega območja znaša $3.236 \mathrm{~km}^{2}$ in obsega 307 k. o. iz časa FK. Povprečna velikost k. o. znaša 10,5 $\mathrm{km}^{2}$ (slika 11.2).

Analiza podatkov, zbranih $\mathrm{v}$ prostorski podatkovni bazi, je bila razdeljena v šest sklopov:

- značilnosti obravnavanega območja,

- demografski podatki,

- podatki o živini,

- povezava med fizičnogeografskimi, demografskimi in ekonom-

skimi podatki,

- podrobnejša prostorsko-statistična analiza živine,

- $\quad$ analiza števila živine na gospodinjstvo.

Rezultati vseh naštetih prostorskih analiz so predstavljeni na kartografskih prikazih. Večina izdelane kartografije kot način prikaza razredov vrednosti uporablja metodo postavljanja naravnih meja med podatki (jenks), saj le-ta najnazorneje prikaže razporeditev vrednosti. Pri tem načinu določanja mej med razredi podatkov so si vrednosti v posameznem razredu čim podobnejše, standardna deviacija znotraj razreda je čim manjša, razlika med posameznimi razredi pa je čim večja. Meje razredov sovpadajo $\mathrm{z}$ velikimi skoki $\mathrm{v}$ vrednostih podatkov. $\mathrm{Z}$ drugimi besedami, metoda klasifikacije poskuša zmanjšati razlike znotraj razredov in povečati razlike med razredi ter razlike $\mathrm{v}$ vrednostih podatkov čim nazorneje prikazati (ESRI 2008).

\subsection{Značilnosti obravnavanega območja}

Preučevano območje se razteza od Jadranskega morja do Julijskih Alp in obsega zahodni del Slovenije. V severnem delu ga na zahodu omejuje današnja državna meja z Italijo, južno od Gorice pa se razteza tudi zahodno od današnje državne meje $\mathrm{z}$ Italijo, saj obsega zgodovinsko povezano območje. Obravnavano območje pa ne vključuje mesta Trst z najbližjo (nekraško) okolico, ker je bilo to že razmeroma visoko urbanizirano, poudarek raziskave pa je na podeželju. Na jugu se območje razteza do današnje državne meje s Hrvaško in obsega celotne Brkine do reke Reke. Vzhodna meja obravnavanega območja je najbolj razgibana, saj poteka zahodno od Ilirske Bistrice do Divače in Ajdovščine, vzhodno od Banjšic in Trnovskega 


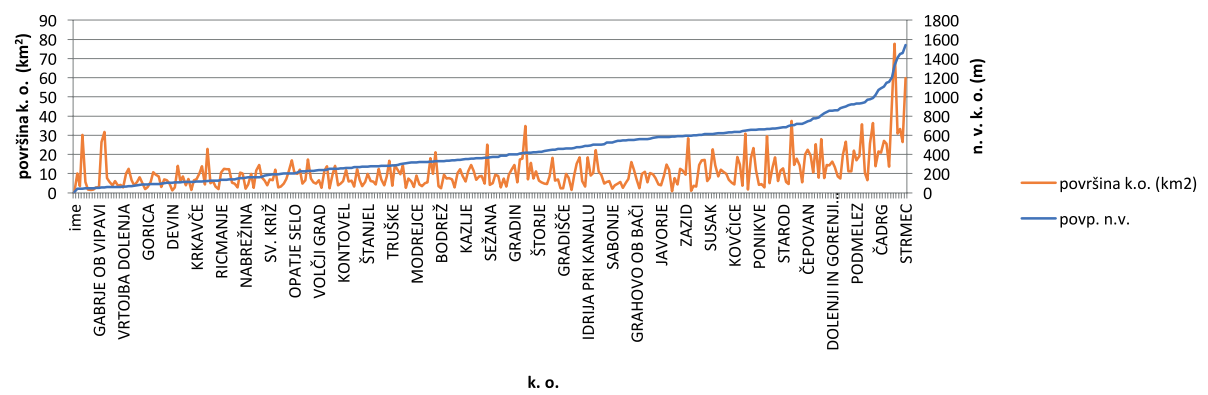

Graf II.r: Prikaz razmerja med površino k. o. in povprečno nadmorsko višino k. o.

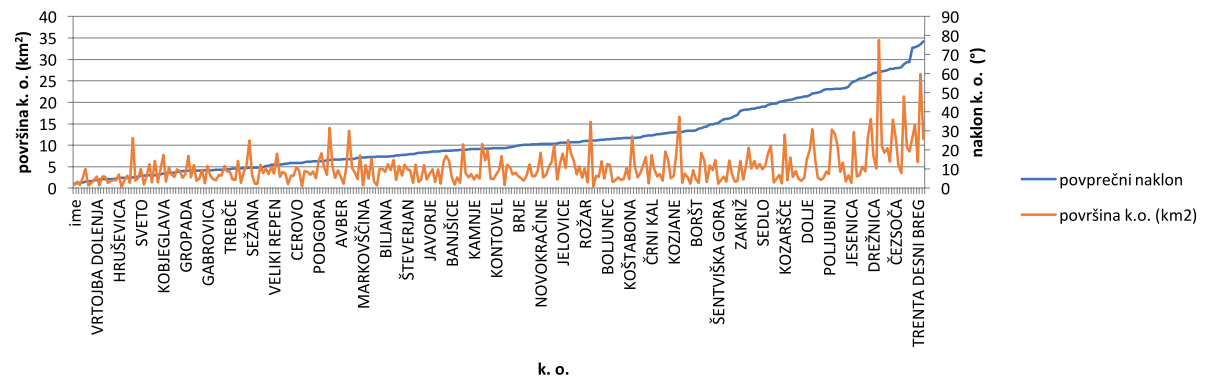

Graf II.2: Prikaz razmerja med površino k. o. in povprečnim naklonom k. o.

gozda, vzhodno od Cerknega, jugozahodno od Bohinja do Trente ter na severu do Mangarta.

Nadmorske višine se gibljejo med o in približno $2.800 \mathrm{~m}$ na skrajnem severu območja. Najnižje nadmorske višine so v obalnem delu, v Vipavski dolini in na Goriškem. Najvišje nadmorske višine so prisotne v Julijskih Alpah in Trnovskem gozdu (slika 11.3).

Naklon je najvišji v alpskem delu območja, v splošnem pa bi lahko rekli, da na približno polovici območja (južni) prevladuje teren z manjšimi nakloni, na severni polovici pa teren $\mathrm{z}$ večjimi nakloni. Meja med njima poteka čez Gorico in Ajdovščino. $\mathrm{V}$ severnem delu tako razmejenega območja se pojavljajo nakloni tudi do $70^{\circ}$, prevladujejo pa nakloni med 20 in $40^{\circ}$. V južnem delu območja so nakloni veliko nižji, običajno ne presegajo $25^{\circ}$, prevladujejo pa nakloni pod $15^{\circ}$ (slika 11.4).

Katastrske občine so zelo različnih velikosti. Opazna je povezava med velikostjo k. o. in nadmorsko višino ter naklonom območja. Največje k.o. se pojavljajo na strmem goratem območju, najmanjše pa na Krasu in v koprskem zaledju. V strmejših goratih predelih je bilo obdelovalne zemlje malo, 
gostota prebivalstva pa manjša, k. o. pa zato obsežnejše. Največje so bile na bovškem in v Trenti, kjer njihova velikost znaša med 30 in $80 \mathrm{~km}^{2}$. Izjemo v velikosti k.o. predstavljajo obalne k. o., ki so prav tako nekoliko večje od povprečja, ki znaša $10,5 \mathrm{~km}^{2}$ (slika 11.5). Povezavo med velikostjo k.o. in nadmorsko višino ter naklonom potrjujeta tudi grafa 11.1 in 11.2, iz katerih lahko razberemo, da je velikost k. o. premo sorazmerna $\mathrm{z}$ nadmorsko višino in naklonom, kar pomeni, da so največje k. o. na goratem, višje ležečem in strmejšem ozemlju. To potrjuje, kar je razvidno tudi iz karte (slika 11.5), in sicer da so največje k. o. v Alpah.

\section{Demografska slika}

V okviru analize demografskih značilnosti smo obravnavali število in gostoto prebivalstva po k. o. (sliki 11.6 in 11.7). Po številu prebivalstva izstopa skrajni SZ del Slovenije, Posočje med Gorico in Tolminom, Goriška, manjši del Krasa in obalno območje. Območja, kjer prevladujejo k. o. z manjšim številom prebivalstva, so predvsem na Krasu, v koprskem zaledju, Čičariji in Brkinih. Na območju Trente se pojavljajo nekatere k. o., za katere nimamo podatka o številu prebivalstva, zato dejansko ne gre za območje, kjer je prisotno izrazito majhno število prebivalstva, kot je videti na karti (slika 11.8). Število prebivalstva je največje v k.o. Gorica (8.284 ljudi), Piran (7.942 ljudi) in Koper (5.446 ljudi), najmanjše pa v k. o. Vrtoče (58 ljudi), Ritomeče (67 ljudi) in Gabrk (71 ljudi).

Skupno število prebivalstva na celotnem preučevanem območju znaša 171.029 ljudi: tolikšno je torej bilo leta 1827 prebivalstvo Primorske brez Trsta. V kolikor izvzamemo izrazito mestne k. o. (Gorica, Koper in Piran), število prebivalstva na primorskem podeželju znaša 149.357 ljudi.

Poleg skupnega števila je relevantna informacija tudi gostota prebivalstva na $\mathrm{km}^{2}$ za vsako $\mathrm{k}$. o., nenazadnje zaradi tega, ker se velikosti posameznih k.o. med seboj zelo razlikujejo. V primerjavi s skupnim številom je slika gostote prebivalstva bistveno drugačna (slika 11.9): izstopata še vedno obala in Goriška, nato pa Kras, tržaško zaledje in okolica Tolmina. Gostota prebivalstva na $\mathrm{km}^{2}$ je največja v k. o. Koper (11.349 ljudi na km²), sledita Gorica (4.374 ljudi na $\mathrm{km}^{2}$ ) in Rupa (645 ljudi na $\mathrm{km}^{2}$ ). Razlog za izjemno gostoto v k. o. Koper je, da je obsegala samo otok, k. o. Piran, ki je po številu prebivalstva na drugem mestu, pa obsega tudi zaledje in Portorož. Podobno kot za k. o. Koper velja tudi za k. o. Gorica, saj tudi Gorica obsega le staro mesto brez zaledja. Najmanjša gostota se pojavlja v k. o. Gorenji Log (6 ljudi na $\mathrm{km}^{2}$ ), Trenta desni breg (6 ljudi na $\mathrm{km}^{2}$ ) in Čadrg (11 ljudi 
na $\mathrm{km}^{2}$ ). Razlika med k. o. z največjo in najmanjšo gostoto je zelo velika, v k. o. Koper je gostota kar 1891-krat večja kot v Gorenjem Logu in Trenti desni breg. Vse tri k .o. z najmanjšo gostoto se nahajajo v nizko poseljenem goratem skrajnem severovzhodu območja.

Povprečna gostota prebivalstva na $\mathrm{km}^{2}$ za celotno območje znaša 56 ljudi na $\mathrm{km}^{2}$. Če tudi pri gostoti prebivalstva, podobno kot pri številu, iz analize izvzamemo urbane k. o. (Gorica, Koper in Piran), znaša povprečna gostota prebivalstva na podeželskem delu 50 ljudi na $\mathrm{km}^{2}$, iz česar izhaja, da je bilo $\mathrm{v}$ prvi polovici 19. stoletja primorsko podeželje razmeroma gosto poseljeno.

V sklopu demografskih značilnosti smo analizirali tudi razmerje med moškimi in ženskami po posameznih k. o. (slika 11.8). Vrednosti, večje od 1 , obarvane $\mathrm{v}$ vijoličasti in modri barvi, pomenijo več moških, vrednosti manjše od 1, obarvane $z$ rumeno in oranžno barvo, pomenijo več žensk. Iz prostorske razporeditve števila moških in žensk po posameznih k.o. ni opaziti izrazitejših prostorskih zakonitosti ali izstopanja posameznih predelov ozemlja. Po številu žensk najbolj izstopajo k. o. Prosek (o,725 moških na 1 žensko), k. o. Rožar (o,732 moških na 1 žensko) in Gabrje ob Vipavi (o,766 moških na 1 žensko). Po številu moških najbolj izstopajo k. o. Gabrk $(1,448$ moških na 1 žensko), Šempeter $(1,447$ moških na 1 žensko) in Vrtoče $(1,416$ moških na 1 žensko).

\section{Tabela II.I: Število in gostota prebivalstva po posameznih podobmočjih}

Število prebivalstva

\begin{tabular}{lcc} 
Julijske Alpe & 604 & 11,6 \\
\hline Bovec, Trenta & 5.626 & 29,0 \\
\hline Zg. Posočje & 18.479 & 42,6 \\
\hline Sp. Posočje & 12.340 & 53,6 \\
\hline Cerkljansko hribovje & 9.979 & 46,4 \\
\hline Trnovski gozd & 5.669 & 29,6 \\
\hline Goriška & 33.190 & 123,1 \\
\hline Vipavska dolina & 6.882 & 93,0 \\
\hline Kras & 36.064 & 54,2 \\
\hline Brkini, Podgrajsko podolje & 8.269 & 40,3 \\
\hline Čičarija & 4.520 & 26,8 \\
\hline Koprsko zaledje & 12.372 & 52,3 \\
\hline Obalno območje & 17.035 & 200,0 \\
\hline
\end{tabular}

Tabela 11.1 prikazuje gostoto in število prebivalstva po posameznih podobmočjih. Najvišjo gostoto dosega obalno območje, saj zajema sko- 
raj izključno mesta, najmanjšo pa območje Julijskih Alp, ki je zelo redko poseljeno. Podobno gostoto, kot je povprečje za celotno območje, dosegajo Kras, koprsko zaledje in Spodnje Posočje. Območja s podpovprečno gostoto so Julijske Alpe, Bovec in Trenta, Zgornje Posočje, Cerkljansko hribovje, Trnovski Gozd, Brkini in Podrgajsko podolje ter Čičarija. Izmed pretežno podeželskih območij po razmeroma visoki gostoti prebivalstva izstopa Vipavska dolina.

Za nekatere k. o. razpolagamo tudi s podatkom o številu gospodinjstev, ki pa ni bil popisan povsod, zato ne omogoča analize in primerjave za celotno obravnavano ozemlje. Podatek je zajet pri $181 \mathrm{k}$. o., kar predstavlja 58 \% vseh k. o. Ker pa je na njegovi podlagi možno izračunati povprečno število članov gospodinjstev, smo ga kljub temu vključili v analizo. Slika 11.9 prikazuje tiste k. o., za katere je bil podatek o številu gospodinjstev popisan, in iz nje je razvidno, da manjka na območju Trnovskega gozda, Krasa, na obalnem območju ter delno v koprskem zaledju in Brkinih. Slika 11.10 prikazuje povprečno število članov gospodinjstva: po večjem številu izstopajo Cerkljansko hribovje, Julijske Alpe, Zgornje Posočje, Brkini s Podgrajskim podoljem in Čičarija.

Da so demografske značilnosti tesno povezane s fizičnogeografskimi značilnosti, je bilo vidno že v predhodnih analizah, na tem mestu pa smo poskušali prikazati neposredno povezavo med gostoto prebivalstva po $\mathrm{k}$. o., nadmorsko višino k. o. in naklonom k. o. Graf 11.3 prikazuje odnos med gostoto prebivalstva, naklonom ter nadmorsko višino in nam potrjuje, da je rast gostote prebivalstva obratno sorazmerna $\mathrm{z}$ rastjo naklona in nadmorske višine. Mejna vrednost nadmorske višine, po kateri se $\mathrm{k}$. $\mathrm{o}$. $\mathrm{z}$ večjo gostoto ne pojavljajo več, je okrog $400 \mathrm{~m}$, naklon pa okrog $20^{\circ}$.

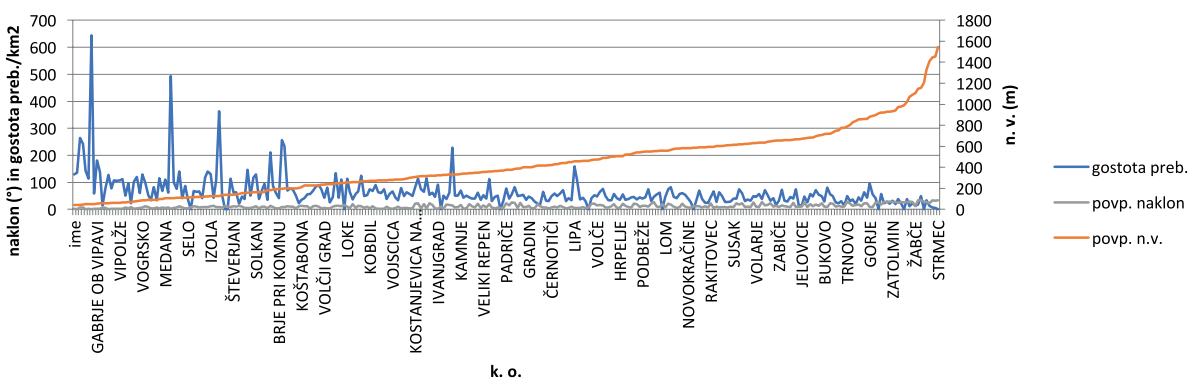

Graf II.3: Razmerje med gostoto prebivalstva, povprečnim naklonom in povprečno nadmorsko višino k. o. 


\section{Slika živinoreje}

Analiza ekonomskih podatkov se je osredotočila na analizo podatkov o posameznih vrstah živine, pridobljenih iz cenilnih operatov franciscejskega katastra. Izvedena je bila na 3 načine:

- analiza števila posameznih vrst živine po k. o.,

- analiza gostote posameznih vrst živine na $\mathrm{km}^{2}$,

- $\quad$ analiza števila živine na prebivalca.

Za navedene tri analize in prikaze smo se odločili, ker smo želeli ugotoviti, kje je neka vrste živine prisotna ter s čim je povezana, bodisi s fizično-geografskimi značilnostmi območja ali z gostoto prebivalstva. Enostavni prikaz na osnovi števila živine v posameznih k.o. namreč ne daje relevantnejših rezultatov, saj so k. o. zelo različno velike. Bistveno povednejša je prostorska slika, ki jo dobimo na osnovi informacije o gostoti živine na $\mathrm{km}^{2}$, saj nam pokaže, kje se določena vrsta živinoreje izraziteje pojavlja, medtem ko nam število živine na prebivalca prikaže jasno sliko o tem, kje so se z njo intenzivneje ukvarjali. Ko med seboj primerjamo rezultate vseh treh analiz, lahko pojavljanje neke dejavnosti razumemo kompleksneje in temeljiteje.

Posebno težavo je pri tem predstavljala nedoslednost podatkov v cenilnih operatih, saj popisane vrste živine niso povsod iste, obenem pa so se ponekod različne vrste živine združevale (na primer ovce in koze). Zato je bilo za analizo potrebno kategorije poenotiti, sicer bi bili podatki neprimerljivi. Naslednje vrste živine so bile v cenilnih operatih FK evidentirane in zavedene v naši bazi: konji, kobile, krave, mule, osli, ovce, ovce in koze, svinje, voli, teleta, kobile, žrebički, kastrirani konji in kastrirani ovni. Ker pa se naštete kategorije niso pojavljale enotno $\mathrm{v}$ vseh k. o., smo v nadaljnjo obdelavo podatke zaobjeli naslednje skupine živali: konje, kobile, krave, mule, osle, ovce, ovce in koze, svinje, vole in teleta. Za lažjo in smiselnejšo obdelavo, primerjavo in ponazoritve pa smo vpeljali še nekatere nove, združene kategorije. Gre za seštevke nekaterih vrst, ki se v FK pojavljajo samo ponekod. Te so: živina skupaj, vsi konji (seštevek kategorij: konji, kobile, kastrirani konji ter konji in kobile) in vse ovce in koze (seštevek kategorij: ovce, ovce in koze ter kastrirani ovni).

\subsection{Analiza živine po k. o.}

Slika 11.11 predstavlja porazdelitev vse živine ne glede na vrsto. K. o. z največ živine se nahajajo predvsem na SZ, kjer so tudi največje k. o., med 
Tolminom in Cerknim, na Krasu ter v Čičariji. Gostota živine na $\mathrm{km}^{2}$ (slika 11.12) nam prikaže precej drugačno razporeditev, saj največjo gostoto zaznamo v Brikinih in Čičariji ter v Cerkljanskem hribovju. Če v primerjavo vključimo še število živine na prebivalca (slika 11.13), ugotovimo, da ponovno izstopata Čičarija in Trenta. Iz primerjave lahko zaključimo, da je v splošnem živinoreja najbolj izstopajoča na območju Čičarije.

Ker se v posameznih k. o. pojavljajo dodatne kategorije, na primer kobile ali kastrirani konji, smo vse podkategorije združili $v$ eno in jo poimenovali »vsi konji«. Gre za seštevek kategorij konji, kobile, kastrirani konji ter konji in kobile. Iz analize pojavljanja konjev po k. o. lahko razberemo, da se konji pojavljajo predvsem $\mathrm{v}$ okolici večjih mest, $\mathrm{v}$ Čičariji in Trnovskem gozdu, medtem ko nam njihovo število na prebivalca najbolj izpostavi predele okrog Kobarida, Čičarijo in Trnovski gozd (slike 11.14, 11.15 in 11.16).

Po številu krav na k. o. (slika 11.17) najbolj izstopajo višje ležeča območja v Posočju, Trnovskem gozdu in v Cerkljanskem hribovju ter južni del Krasa in Vipavska dolina. Če analiziramo gostoto krav na $\mathrm{km}^{2}$ (slika 11.18), se slika bistveno ne spremeni. Ob upoštevanju števila krav na prebivalca (slika 11.19) pa se izpostavijo še zahodni del Krasa in Čičarija, Brkini ter Podgrajsko podolje.

Mule se pojavljajo zgolj v nekaterih k. o., iz česar je mogoče sklepati, da pri popisovanju niso povsod obstajale kot samostojna kategorija pa tudi da na splošno niso bile zelo prisotne. Vse tri analize (slike 11.20, 11.21 in 11.22) pri pojavljanju mul izpostavijo ista območja; koprsko zaledje, Kras in delno Posočje. Najbolj zastopane so v k. o. Obrov.

Osli se pojavljajo izključno v Primorju, na Goriškem in Krasu. Iz rezultatov vseh treh analiz lahko razberemo, da se najmnožičneje pojavljajo $\mathrm{v}$ koprskem zaledju (slike 11.23, 11.24 in 11.25).

Tudi pri ovcah in kozah so se kategorije popisovanja po različnih k. o. razlikovale. Najprej smo analizirali zgolj kategorijo ovce. Iz analize po k. o. razberemo, da se pojavljajo predvsem na Krasu, Čičariji, Posočju in Cerkljanskem hribovju. Analizi gostote ovc na $\mathrm{km}^{2}$ in na prebivalca nam po številu ovc najbolj izpostavita območje Čičarije (slike 11.26, 11.27 in 11.28).

V nekaterih k. o. je bila uporabljena kategorija ovce in koze, zato smo kategorije ovce, ovce in koze ter kastrirani ovni sešteli v enotno kategorijo in jih analizirali (slike 11.29, 11.30 in 11.31). Poleg območij, ki smo jih našteli že pri predhodni analizi, se sešteta kategorija ovc in koz pojavlja še $\mathrm{v}$ Julijskih Alpah. Na drugih območjih je slika zelo podobna predhodni, kar 
pomeni, da gre za popisovanje po različnih kategorijah v Alpah v primerjavi z drugod. Območja, kjer je ovčereja in kozjereja najbolj prisotna, so Čičarija, Kras, Bovško in Cerkljansko hribovje. Ker je slika za pojavljanje ovc zelo podobna sliki pojavljanja ovc in koz za vsa območja razen Alp, lahko sklepamo, da se na teh območjih pojavlja predvsem ovčereja, ne pa tudi kozjereja.

Iz analize števila svinj po k. o. (slika 11.32) razberemo, da se svinje najizraziteje pojavljajo na Krasu, v Posočju, v obalnem predelu, na Goriškem in v severozahodni Sloveniji. Analiza gostote svinj na $\mathrm{km}^{2}$ (slika 11.33) najbolj izpostavi osrednji del območja (Goriško, del Krasa, del Posočja in Cerkljanskega hribovja ter koprsko zaledje). Število svinj na prebivalca (slika 11.34) pa pokaže precej enakomernejšo sliko; kot območja, kjer svinjereja ni prisotna, izstopajo le Julijske Alpe in delno obalno območje.

Voli (slike 11.35, 11.36 in 11.37) se pojavljajo skoraj povsod razen v višjeležečem alpskem svetu in Posočju, nekoliko manj pa tudi v primorju. Analizi gostote volov na $\mathrm{km}^{2}$ in na prebivalca to potrjujeta, razporeditev pa je še enakomernejša preko celotnega območja, kjer se te živali pojavljajo.

Glede telet (slike 11.38, 11.39 in 11.40) je iz rezultatov analiz možno predvidevati, da niso bila povsod popisana kot samostojna kategorija, saj se na večjem delu ozemlja ne pojavljajo, ali pa da so bila dejansko prisotna samo ponekod. Sicer izstopajo Goriška, del Posočja in Cerkljanskega hribovja, Vipavska dolina in Brkini.

\subsection{Povezava med fizičnogeografskimi značilnostmi in živinorejo}

$\mathrm{V}$ nadaljevanju smo poskušali analizirati povezavo nadmorske višine in pojavljanje posameznih vrst živine. Iz grafov 11.4 in 11.5 lahko razberemo, da je pojavljanje oslov in konjev obratno sorazmerno povezano $z$ nadmorsko višino. Posebej izrazito je to pri oslih, ki se pojavljajo zgolj v nižjeležečih, južnih predelih preučevanega območja.

Grafa 11.6 in 11.7 prikazujeta, kako število krav, ovc in koz narašča premo sorazmerno $\mathrm{z}$ nadmorsko višino. $\mathrm{V}$ najvišjih nadmorskih višinah pa se pojavljajo le še ovce in koze, število krav upade. Grafa 11.8 in 11.9 prikazujeta manj intenzivno, obratno sorazmerno povezavo med svinjami in voli ter nadmorsko višino. Svinje in voli se pojavljajo predvsem na nižjih in zmernih nadmorskih višinah. 


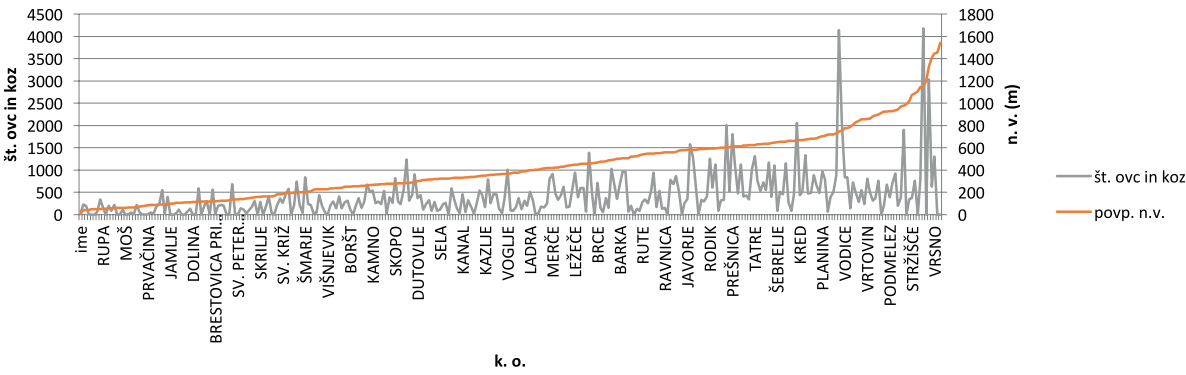

Graf II.4: Razmerje med številom konjev k. o. in povprečno nadmorsko višino k. o.

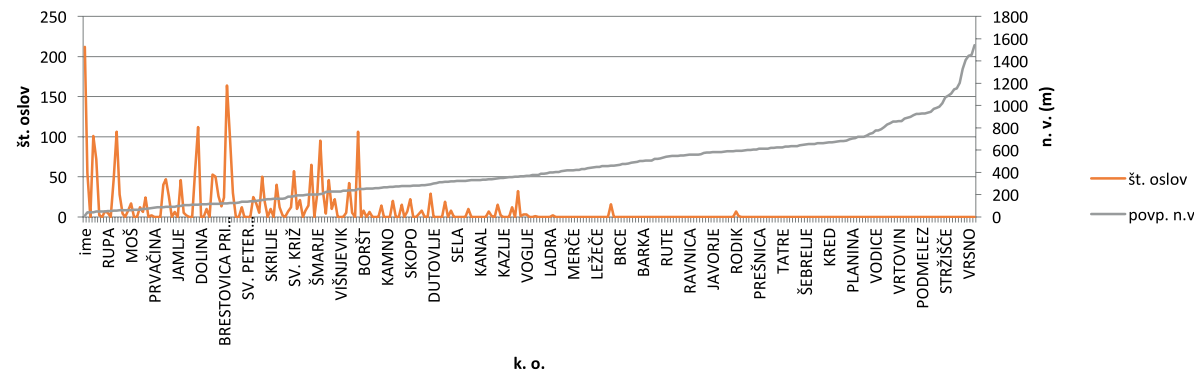

Graf II.5: Razmerje med številom oslov po k. o. in povprečno nadmorsko višino k. o.

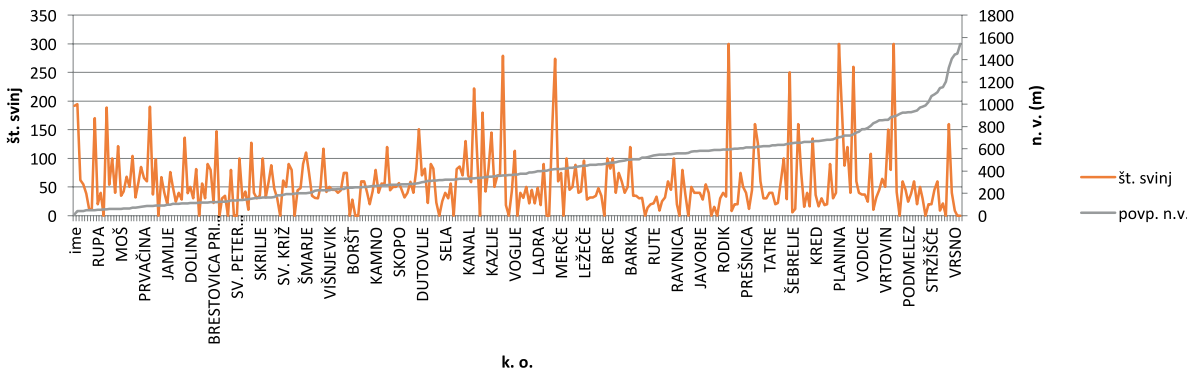

Graf II.6: Razmerje med številom krav po k. o. in povprečno nadmorsko višino k. o.

\subsection{Podrobnejša prostorsko-statistična analiza živine}

Pojavljanje živine smo analizirali tudi $\mathrm{z}$ dvema prostorsko statističnima metodama za naslednje vrste živine: konji (vsi), krave, ovce in koze (vse), svinje, voli ter osli. Izdelali smo elipso standardne deviacije, ki prikazuje ponazoritev trenda razporeditve pojava $\mathrm{v}$ prostoru $\mathrm{z}$ elipso, izrisano na podlagi izračuna standardne deviacije po osi $\mathrm{x}$ in y Elipsa standardne de- 


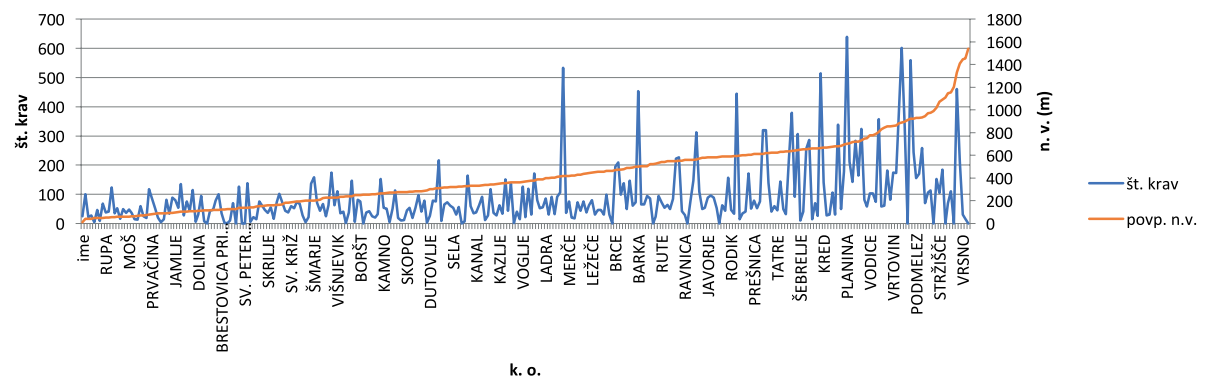

Graf ıı.7: Razmerje med številom ovc in koz po k. o. ter povprečno nadmorsko višino k. o.

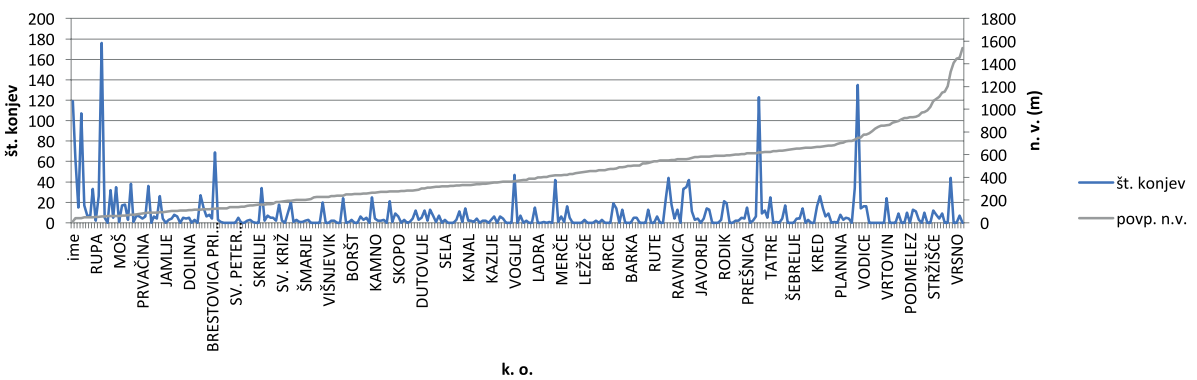

Graf II.8: Razmerje med številom volov po k. o. in povprečno nadmorsko višino k. o.

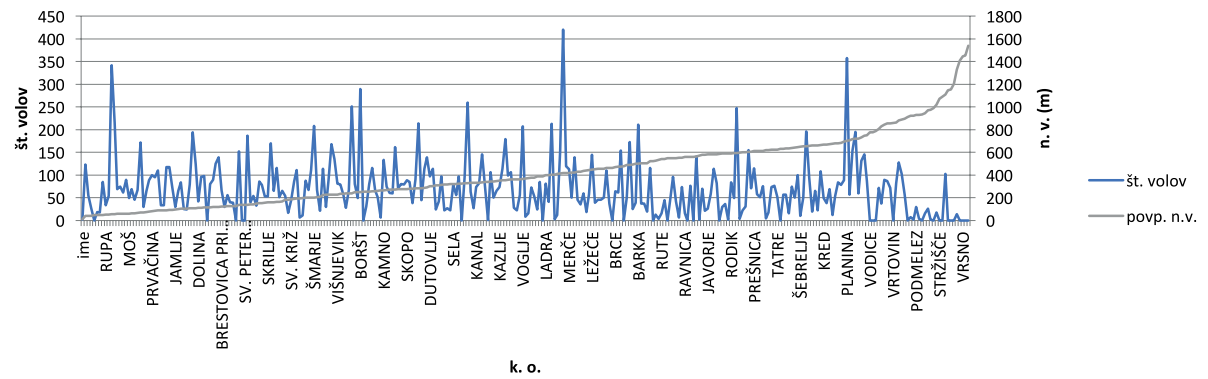

Graf II.9: Razmerje med številom svinj po k. o. in povprečno nadmorsko višino k. o.

viacije prikaže standardno deviacijo po osi $\mathrm{x}$ in $\mathrm{y}$ ter $\mathrm{s}$ tem ponazori trend razporeditve pojava $\mathrm{v}$ prostoru. $\mathrm{V}$ povprečju se znotraj elipse nahaja približno 68 \% populacije, v našem primeru posameznih vrst živine (ESRI Inc. 2013).

Elipse standardne deviacije smo izdelali za posamezne vrste živine glede na število živine po k. o. (slika 11.41), po gostoti živine na $\mathrm{km}^{2}$ (sli- 
ka 11.42) in po številu živine na prebivalca (slika 11.43). Po prostorski razporeditvi izstopa predvsem pojavljanje oslov, ki so zastopani samo na jugu, in krav, ki so zastopane predvsem v severno-osrednjem delu. V osrednjem delu, ki zajema del Goriške, Krasa in Posočja, se pojavljajo vse vrste živine z izjemo oslov, ki se pojavljajo le na Krasu. Med elipsami standardne deviacije glede na število posameznih vrst živine po k. o., gostoti na $\mathrm{km}^{2}$ in na prebivalca ne prihaja do večjih razlik. Največja razlika se pokaže pri oslih, kjer se pri prikazu gostote na $\mathrm{km}^{2}$ skoncentrirajo na manj obsežno območje koprskega zaledja in Krasa.

$\mathrm{V}$ nadaljevanju so predstavljeni rezultati še ene prostorsko statistične analize, in sicer analize hot spot ali analize vročih in hladnih točk. Analiza vročih in hladnih točk prikaže t. i. vroče in hladne točke pojavljanja posameznih vrste živine. Vroče točke so k. o., v katerih je število neke vrste živine veliko ter obkroženo s k. o., kjer je število prav tako veliko (na slikah obarvano z odtenki rdeče). Hladne točke pa so k. o., v katerih je število neke vrste živine majhno ter obkroženo s k. o., kjer je število prav tako majhno (na slikah obarvano z modrimi odtenki). Statistično nepomembne (na slikah obarvano $z$ rumenimi odtenki) so pri tovrstni analizi k. o., kjer živalske vrste ni ali ne prihaja do območij zgoščanja visokih oz. nizkih vrednosti (ESRI Inc. 2013).

Za razliko od zgolj ponazoritev števila živine po k. o., gostote po $\mathrm{km}^{2}$ in na prebivalca ter elips standardne deviacije pri analizi vročih in hladnih točk prihaja do večjih odstopanj in razlik. Dejansko nam šele analiza vročih in hladnih točk pokaže najintenzivnejša območja zgoščanja neke dejavnosti, kjer se je prebivalstvo z neko vrsto živinoreje intenzivneje ukvarjalo, to je, kateri deli območja so bili izrazito usmerjeni v nek tip živinoreje. Posebej je potrebno omeniti, da območja, kjer med posameznimi k. o. prihaja do velikih razlik v številu neke vrste živine, analiza vročih in hladnih točk ne izpostavi oz. takšna območja uvrsti v enako kategorijo kot tista območja, kjer omenjene živalske vrste ni.

Iz pregledov števila konjev na $\mathrm{k}$. o., gostote na $\mathrm{km}^{2}$ in na prebivalca smo ugotovili, da se konji pojavljajo predvsem v okolici mest. Vroče točke (slike 11.44, 11.45 in 11.46) števila konjev na k. o. nam to potrjujejo. Največja gostota konjev je v okolici Kobarida, Gorice, na obalnem območju ter v Čičariji. Glede na površino imamo opraviti samo z eno vročo točko, to je Koper z okolico, posod drugod, upoštevajoč površino, ne prihaja do območij zgoščanja. Vroče točke v razmerju do števila prebivalstva nam dajo popolnoma drugačno sliko. Izstopajo območja, kjer je prebivalstva manj, 
kot na primer okoli Kobarida, Trnovski gozd in Čičarija. Na območjih, ki so obarvana $\mathrm{z}$ rumeno, ne prihaja do območij zgoščanja visokih ali nizkih vrednosti, zato rumenih območij ne smemo razumeti, kot da se tam neka vrsta živine, v tem primeru konji, nujno ne pojavlja. Lahko gre le za to, da so k. o. z visokimi in nizkimi vrednostmi prostorsko mešano razporejene.

Pojavljanje oslov je zelo prostorsko omejeno na nižja, južnejša in toplejša območja, zato tudi analiza vročih in hladnih točk ne pokaže veliko novega (slike 11.47, 11.48 in 11.49). Vzreja oslov je prisotna predvsem v primorju. $\mathrm{Na}$ Goriškem so zastopani bistveno manj.

Pri analizi vročih in hladnih točk (slike 11.50, 11.51 in 11.52) govedoreje je zanimiva delitev sever-jug, ki pade najprej v oči. Govedoreja je izrazito prisotna na severnem, višjeležečem delu območja, z izjemo alpskega sveta. Območja na Krasu, Goriškem in v primorju so prepoznana kot hladne točke, kar pomeni, da je govedoreja prisotna $\mathrm{v}$ enakomerno nizkem številu preko celotnega območja. Analiza nam potrjuje, da je govedoreja najprisotnejša predvsem $\mathrm{v}$ višjem hribovitem (ne goratem) svetu in na kraških planotah.

Vroče točke ovčereje in kozjereje (slike 11.53, 11.54 in 11.55) so prisotne na severu in jugu: $v$ Alpah, Trenti in na Bovškem, $v$ Cerkljanskem hribovju ter v Čičariji, Brkinih, Podgrajskem podolju. Goriški in Vipavski dolini ter območju med Koprom in Trstom so prepoznane kot hladne točke, kar pomeni kontinuirano prostorsko prisotnost $\mathrm{v}$ majhnem številu. Velikih razlik v rezultatih vseh treh analiz vročih točk ni, iz česar lahko sklepamo, da sta ovčereja in kozjereja bolj povezani z ozemeljskimi značilnostmi kot s prebivalstvom. Če karte vročih točk primerjamo s kartami števil, gostote in števila konjev na prebivalca, ugotovimo, da izstopajo tri območja, na katerih se ovce in koze pojavljajo, vendar niso prepoznana ne kot vroče ne kot hladne točke. Gre za območja Krasa, Cerkljanskega hribovja in Spodnjega Posočja. Razlog je v tem, da se na teh območjih število ovc in koz med posameznimi k. o. zelo razlikuje, zato niso prepoznana kot območja zgoščanja.

Rezultati analiz vročih in hladnih točk pojavljanja števila svinj (slike $11.56,11.57$ in 11.58) na k. o., na površino in na prebivalca dajejo med seboj zelo različne rezultate. Vroče območje pojavljanja svinjereje je prisotno na južnem delu Posočja in v Cerkljanskem hribovju ter v okolici Kopra. Svinjereja je prisotna praktično povsod, ni pa zelo izrazitih območij zgoščanja, razen prej naštetih, zato se rezultati analize glede na površino in na število prebivalstva močno razlikujejo. 
Pri volih (slike 11.59, 11.60 in 11.61) ponovno ne prihaja do zelo velikih razlik med tremi analizami vročih in hladnih točk. Kot najizrazitejša vroča območja so prepoznani Goriška, južni del Posočja in Vipavska dolina. Rezultati analize vročih točk pojavljanja volov glede na število prebivalstva pa pokažejo vroče območje tudi na Krasu.

Prostorske analize so nam pokazale, da so nekatere dejavnosti oz. vrste živinoreje bolj povezane s poselitvijo, druge z geografskimi značilnostmi območja, na primer nadmorsko višino, bližino mest ipd., vsekakor pa vplivajo še mnogi drugi dejavniki, ki jih iz te analize ni mogoče razbrati. V nadaljevanju bomo poskušali rezultate prostorskih analiz povzeti oz. združiti za posamezna območja. V preglednici 2 so $\mathrm{z}$ "X« označene živali, ki se $\mathrm{v}$ večji meri pojavljajo na posameznih območjih, glede na rezultate vseh narejenih prostorskih analiz, tako glede na število po posameznih k. o., glede na površino na $\mathrm{km}^{2}$ in glede na število prebivalstva. $\mathrm{Z} »(\mathrm{X})$ « so označene tiste vrste, ki so razvidne samo pri prikazih števila, pri analizah vročih in hladnih točk pa niso izpostavljene kot vroča območja.

Julijske Alpe so razmeroma redko poseljene zaradi visokih gora in skoraj edina vrsta živine, ki se tu pojavlja, so ovce in koze, medtem ko so vse ostale vrste skromno zastopane. Na območju Bovca in Trente se nadmorske višine nekoliko znižajo, vendar je večina območja, z izjemo dolin, še vedno težko dostopna in visokoležeča, kar otežuje živinorejo. Poleg ovc in koz so tu v večjem številu prisotni še konji. V zgornjem, severnem delu Posočja se ponovno in izrazito pojavljajo konji, še vedno je močno prisotna ovčereja in kozjereja, ki pa se ji pridružuje govedoreja, v manjši meri pa naletimo tudi na svinje in vole. V spodnjem, južnem Posočju je v večji meri prisotna govedoreja, ki se dejansko izkazuje kot pomembna dejavnost za celotno območje Posočja. Svinjereja in voli so tu prisotnejši kot v Zgornjem Posočju. Za razliko od Zgornjega Posočja je tu ovčereja in kozjereja prisotna bistveno manj izrazito. Podobno kot v Zgornjem Posočju je tudi na območju Cerkljanskega hribovja, saj gre za enotno območje, tako z vidika fizično-geografskih značilnosti kot glede vrst živali, ki se tam pojavljajo. Bistvena razlika v primerjavi s Spodnjim Posočjem pa je le to, da se kozjereja in ovčereja pojavlja izraziteje. Na redkeje poseljenem območju Trnovskega gozda se pojavljata predvsem govedoreja in vzreja konj. Na ožjem goriškem območju so močno zastopani konji in voli ter tudi osli, izrazita je tudi prisotnost svinjereje. $\mathrm{V}$ Vipavski dolini je močno zastopana govedoreja in voli, v manjši meri pa tudi svinjereja. Območje Krasa je z vidika zastopanosti živalskih vrst veliko pestrejše od severnejših območij. Z 
izjemo konjev so tu prisotne vse živalske vrste. Izrazito so zastopani ovčereja, kozjereja, svinjereja in pa voli, vendar sta ovčereja in kozjereja v primerjavi s Posočjem ali Čičarijo zastopani manj. Videti je, da so na osrednjem delu Krasa močno prisotne svinjereja in ovčereja oz. kozjereja, govedoreja pa je prisotna le ponekod in manj izrazito kot na primer v Posočju in v Cerkljanskem hribovju. Prisotni so tudi osli, vendar ne tako izrazito kot v primorju. Brkini in Podgrajsko podolje so ponovno manj poseljeno območje, tu sta izrazito prisotni ovčereja in kozjereja, ki predstavljata osrednjo dejavnost v sklopu živinoreje. V manjši meri so zastopane tudi govedoreja, svinjereja in voli. Posebej zanimivo je območje Čičarije, kjer je močno prisotna vzreja konj, pomembno dejavnost predstavljajo še ovčereja in kozjereja in pa voli. $\mathrm{V}$ manjši meri je prisotna tudi govedoreja. V koprskem zaledju z izjemo oslov ni močno zastopana nobena vrsta živine. Pojavljata se svinjereja in voli, a v manjši meri. Iz tega lahko sklepamo, da živinoreja tu ni bila močno razvita. V obalnem območju so močno zastopani konji, kot v vseh ostalih mestnih območjih, ter osli, ki so tu dopolnjevali konje in služili kot delovne živali. Močno je zastopana tudi svinjereja

Tabela Ir.2: Območja pojavljanja posameznih vrst živine

\begin{tabular}{|c|c|c|c|c|c|c|}
\hline & Konji & Osli & Krave & $\begin{array}{l}\text { Ovce, } \\
\text { koze }\end{array}$ & Svinje & Voli \\
\hline Jul. Alpe & & & & $\mathrm{X}$ & & \\
\hline Bovec, Trenta & (X) & & & $\mathrm{X}$ & & \\
\hline Zg. Posočje & $\mathrm{X}$ & & $\mathrm{X}$ & $\mathrm{X}$ & $(\mathrm{X})$ & $(\mathrm{X})$ \\
\hline Sp. Posočje & & & $\mathrm{X}$ & (X) & $\mathrm{X}$ & $\mathrm{X}$ \\
\hline Cerkljansko hribovje & & & $\mathrm{X}$ & $\mathrm{X}$ & $\mathrm{X}$ & $\mathrm{X}$ \\
\hline Trnovski gozd & $\mathrm{X}$ & & $\mathrm{X}$ & & & \\
\hline Goriška & $\mathrm{X}$ & $\mathrm{X}$ & & & $\mathrm{X}$ & $\mathrm{X}$ \\
\hline Vipavska dolina & & & $\mathrm{X}$ & & (X) & $\mathrm{X}$ \\
\hline Kras & & (X) & (X) & $\mathrm{X}$ & $\mathrm{X}$ & $\mathrm{X}$ \\
\hline $\begin{array}{l}\text { Brkini, Podgrajsko } \\
\text { podolje }\end{array}$ & & & (X) & $\mathrm{X}$ & (X) & $(\mathrm{X})$ \\
\hline Čičarija & $\mathrm{X}$ & & $(\mathrm{X})$ & $\mathrm{X}$ & & $\mathrm{X}$ \\
\hline Koprsko zaledje & & $\mathrm{X}$ & & & (X) & $(\mathrm{X})$ \\
\hline Obalno območje & $\mathrm{X}$ & $\mathrm{X}$ & & & $\mathrm{X}$ & \\
\hline
\end{tabular}

Kot je bilo navedeno že pri analizi demografskih značilnosti, za nekatere k. o. (58 \% vseh) razpolagamo tudi s podatkom o številu gospodinjstev in za te primere smo lahko ugotovili tudi število živine na gospodinjstvo. Gospodinjstva $z$ največjim številom glav živine (slika 11.62) se pojavljajo na 
območju Julijskih Alp in na Bovškem, v Posočju in v Cerkljanskem hribovju ter v Podgrajskem podolju in Čičariji. Najmanjše število živine na gospodinjstvo je zaslediti na Goriškem.

\section{Sklep}

Pričujoča študija prinaša prvi kvantitativni prikaz podatkov o prebivalstvu in živinoreji za celotno primorsko območje v prvi polovici 19. stoletja, ki smo ga s pomočjo digitalizacije in georeferenciranja katastrskih map nadgradili s prostorsko analizo različno združenih in razčlenjenih podatkov iz cenilnih operatov franciscejskega katastra. Analiziranih je bilo 307 k. o. oz. $3.236 \mathrm{~km}^{2}$ ozemlja.

Skupno število prebivalstva na tem ozemlju je leta 1827 znašalo 171.029 ljudi, povprečna gostota prebivalstva pa je znašala 56,4 ljudi na $\mathrm{km}^{2}$. Najizraziteje poseljena območja so bila Goriška, Vipavska dolina in severni del Krasa, obalno območje in zaledje Trsta ter Spodnje Posočje. K osnovnim podatkom o številu prebivalstva smo dodali razmerje med moško in žensko populacijo, izračun gostote prebivalstva ter za del obravnavanega območja tudi povprečno število članov gospodinjstev.

Zastopanost posameznih vrst živine je mogoče povezati s tipom površja, $\mathrm{z}$ nadmorsko višino ter bližino večjih mest in pomembnih prometnih poti. Analiza nam omogoča razmejitev območij, kjer prevladujejo posamezne vrste živine. Konjereja se pojavlja povsod v bližini večjih mest in prometnih poti, najizraziteje na obalnem območju, Goriškem, Trnovskem gozdu, Čičariji in Zgornjem Posočju. Pojavljanje oslov je tesno povezano s klimatskimi značilnostmi in je vezano na submediteransko podnebje. Pojavljajo se v obalnem območju in njegovem zaledju ter na Goriškem. Območja, kjer je govedoreja najprisotnejša, so vsa ruralna, hribovita (ne gorata) območja, v največji meri Spodnje in Zgornje Posočje, Cerkljansko hribovje, Trnovski gozd in Vipavska dolina. Ovčereja in kozjereja se pojavljata na višjeležečih in bolj odmaknjenih območjih, v največji meri so to Zgornje Posočje, Julijske Alpe, Bovško, Cerkljansko hribovje, Kras, Čičarija, Brkini. Svinjereja je najprisotnejša na nižjih območjih in v bližini mest: Spodnje Posočje, Cerkljansko hribovje, Goriška, Vipavska dolina, Kras, Brkini, obalno območje in njegovo zaledje. Voli se pojavljajo predvsem na območjih Čičarije, Brkinov, Krasa, koprskega zaledja, Goriške, Vipavske doline, Cerkljanskega hribovja in Spodnjega Posočja. Območji, ki sta se $\mathrm{z}$ vidika pojavljanja vrst živine izkazali kot najpestrejši, sta Kras in Zgornje Posočje, najmanj pa območji Julijskih Alp in Trente. Skupno 
število živine na obravnavanem območju znaša 203.158 glav. Izmed analiziranih vrst živine so na splošno najštevilčnejše ovce in koze, ki s skupnim številom 127.292 predstavljajo kar $58 \%$ vse živine. Sledijo krave (27.303 ali $13,4 \%$ ), voli (21.187 ali 10,4\%), svinje (17.633 ali 8,7 \%), konji (2.803 ali 1,4 $\%$ ) in osli (2.577 ali 1,3\%).

Tu izvedena analiza in prikazani rezultati dajejo le osnovno sliko stanja na celotnem ozemlju Primorske, saj gre za razmeroma obsežno območje. Možno bi bilo izvesti podrobnejše analize in primerjave za posamezne katastrske občine ali ožja območja, ki jih lahko prepoznamo kot zanimive, posebne ali pomembne. $S$ tega vidika so rezultati te analize uporabni predvsem kot podlaga in pomoč pri nadaljnjih raziskavah, in sicer ne le geografskega ampak tudi zgodovinskega značaja - za te bi bilo podatke smotrno umestiti $\mathrm{v}$ zgodovinski kontekst in jih povezati $\mathrm{z}$ drugimi znanimi informacijami $\mathrm{z}$ namenom poglobljenejše interpretacije. V vsakem primeru je bila vzpostavljena obsežna prostorska podatkovna baza, ki je poleg navedenega obenem lahko dobra osnova tako za vključitev zbranih podatkov v daljši časovni niz z zgodnejšimi in s poznejšimi obdobji, ki bi pokazal na trende in spremembe skozi čas, kakor za primerjavo $\mathrm{z}$ drugimi slovenskimi in evropskimi območji v istem obdobju, to je v prvi polovici 19. stoletja. 


\section{Priloge - kartografski prikazi}

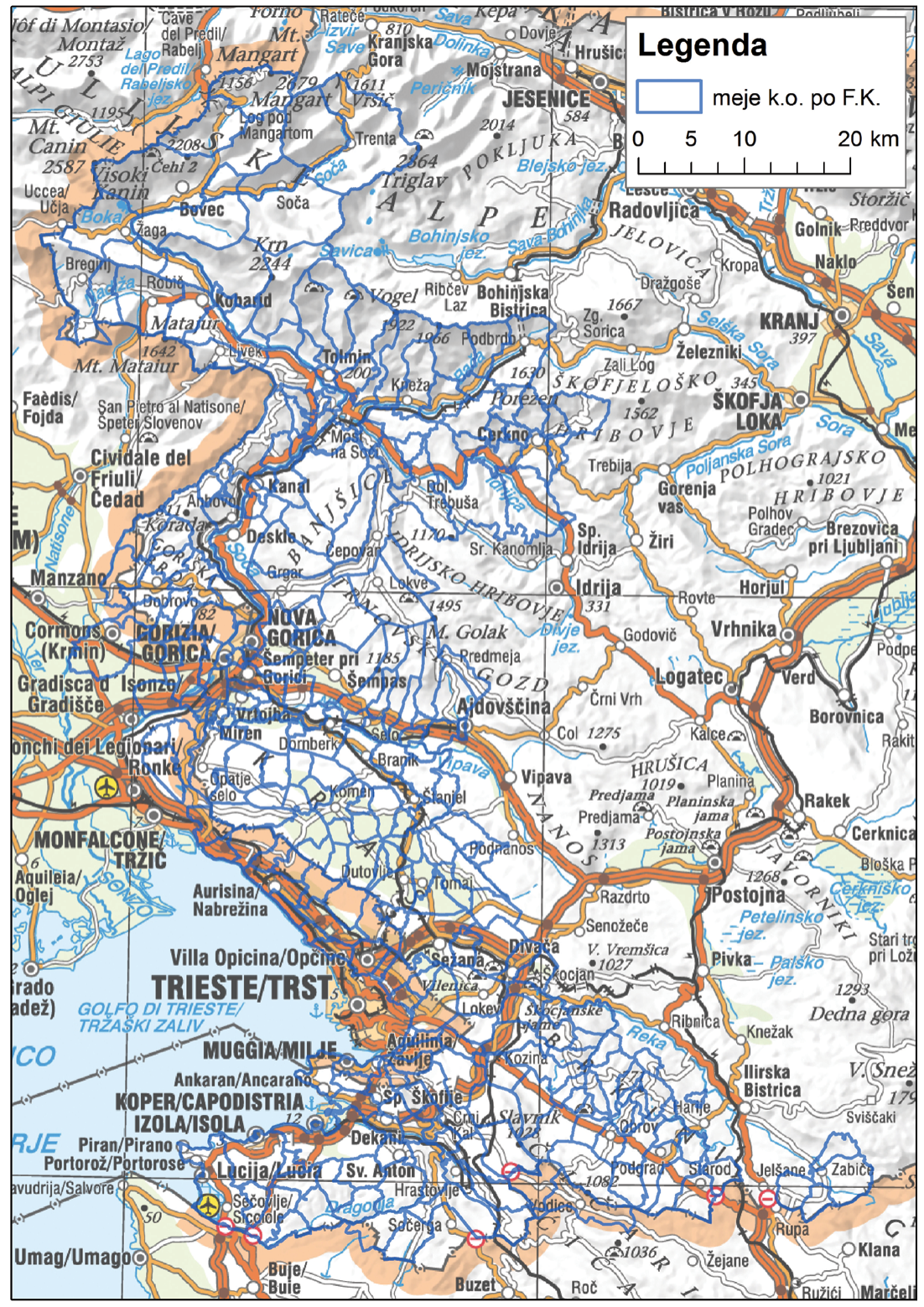

Slika II.2: Prikaz preučevanega območja (avtorica zemljevida: Nataša Kolega, vir podlage: GURS) 

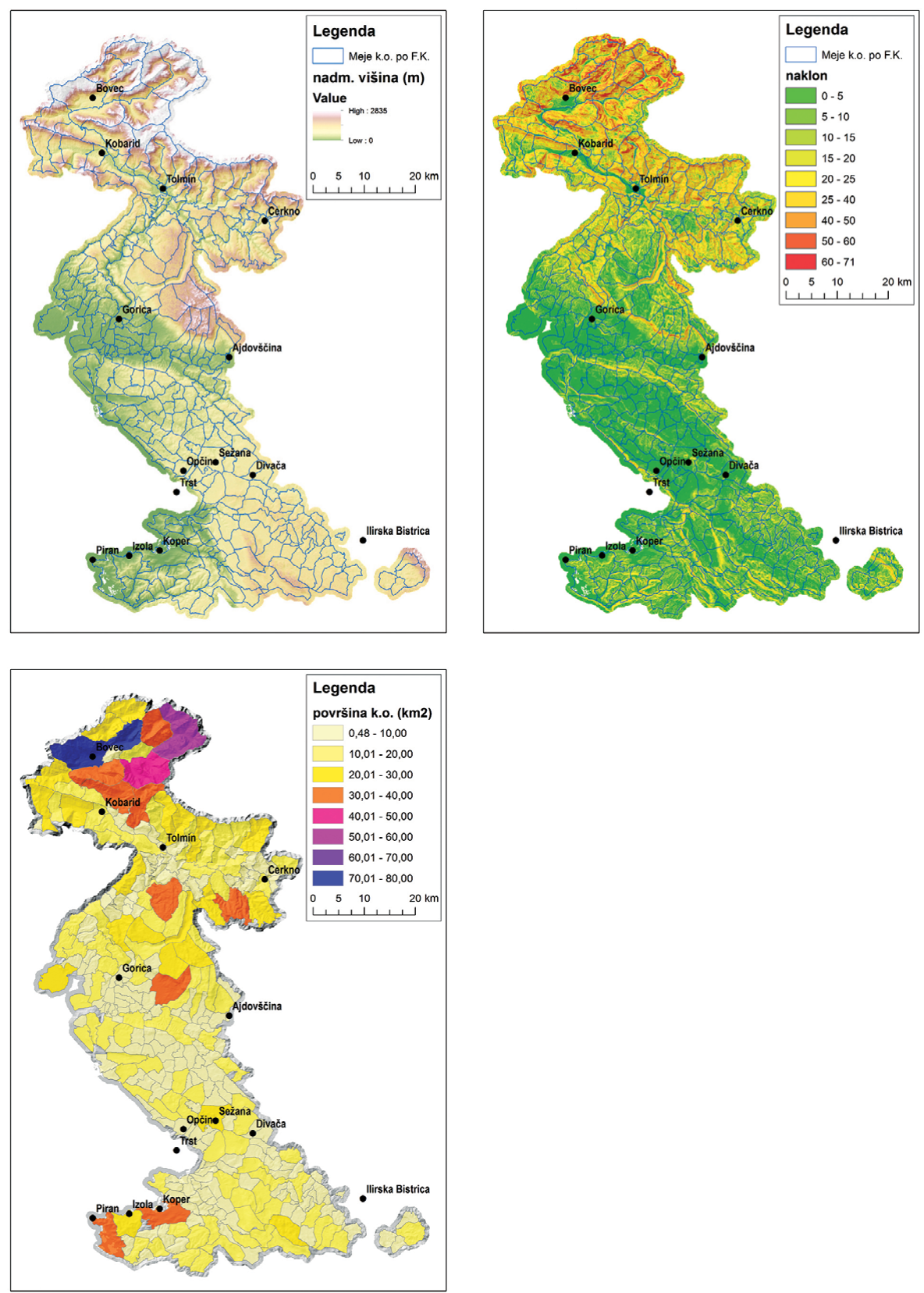

Slike II.3, II.4 in II.5: Nadmorske višine, naklon in površine k. o. (avtorica zemljevida: Nataša Kolega, vir podlage: GURS) 

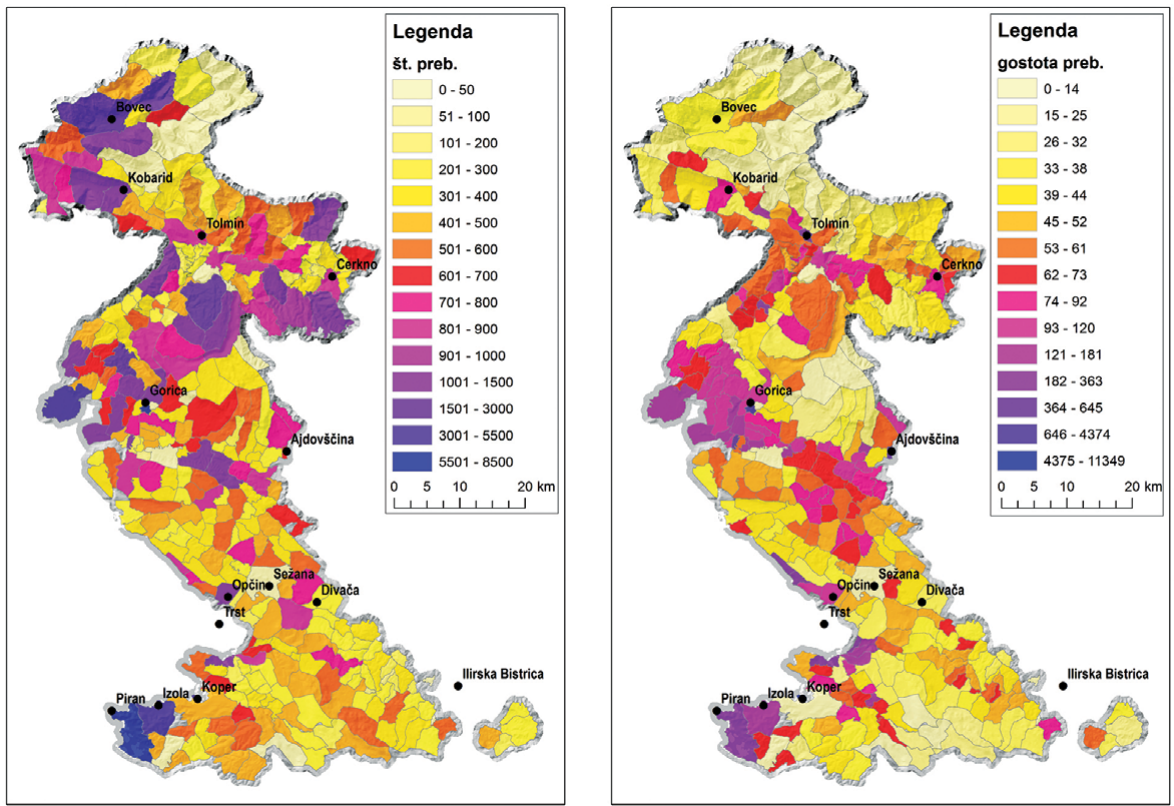

Sliki II.6 in Iı.7: Prikaz števila prebivalstva in gostote prebivalstva na $\mathrm{km}^{2}$ po k. o. (avtorica zemljevida: Nataša Kolega, vir podlage: GURS)

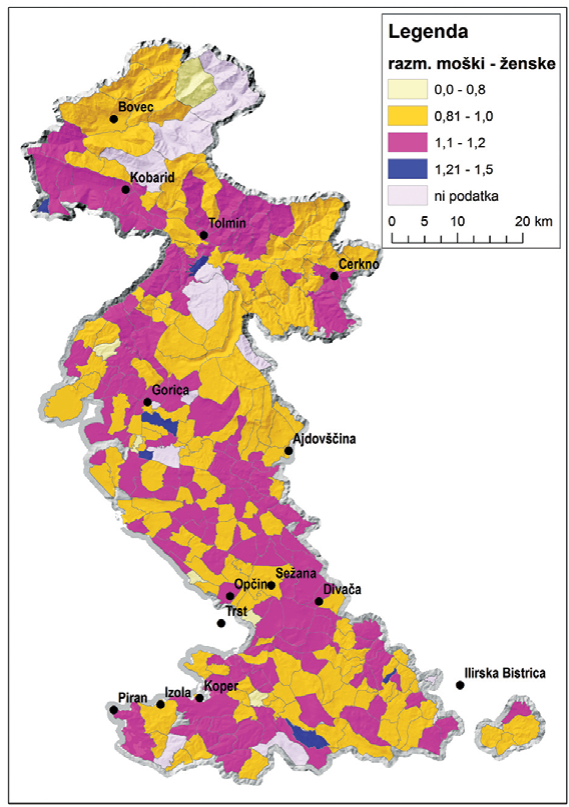

Slika ir.8: Prikaz razmerja med številom moških in žensk po k. o.

(avtorica zemljevida: Nataša Kolega, vir podlage: GURS) 


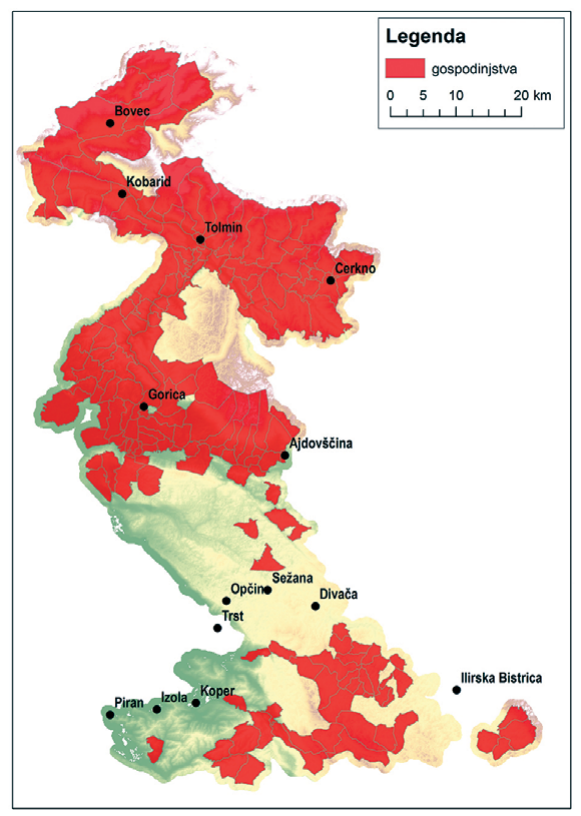

Slika ıı.9: Prikaz k. o., za katere obstaja podatek o številu gospodinjstev

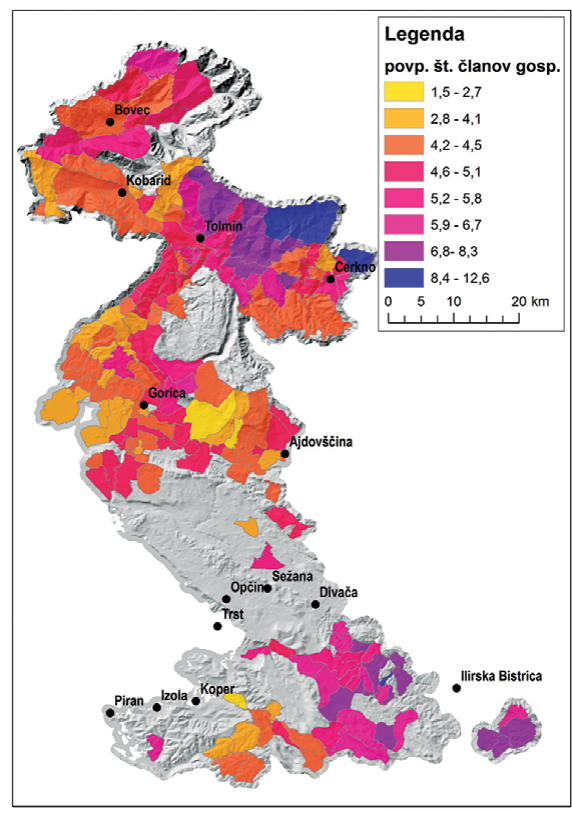

Slika ıı.ıo: Povprečno število članov gospodinjstva 

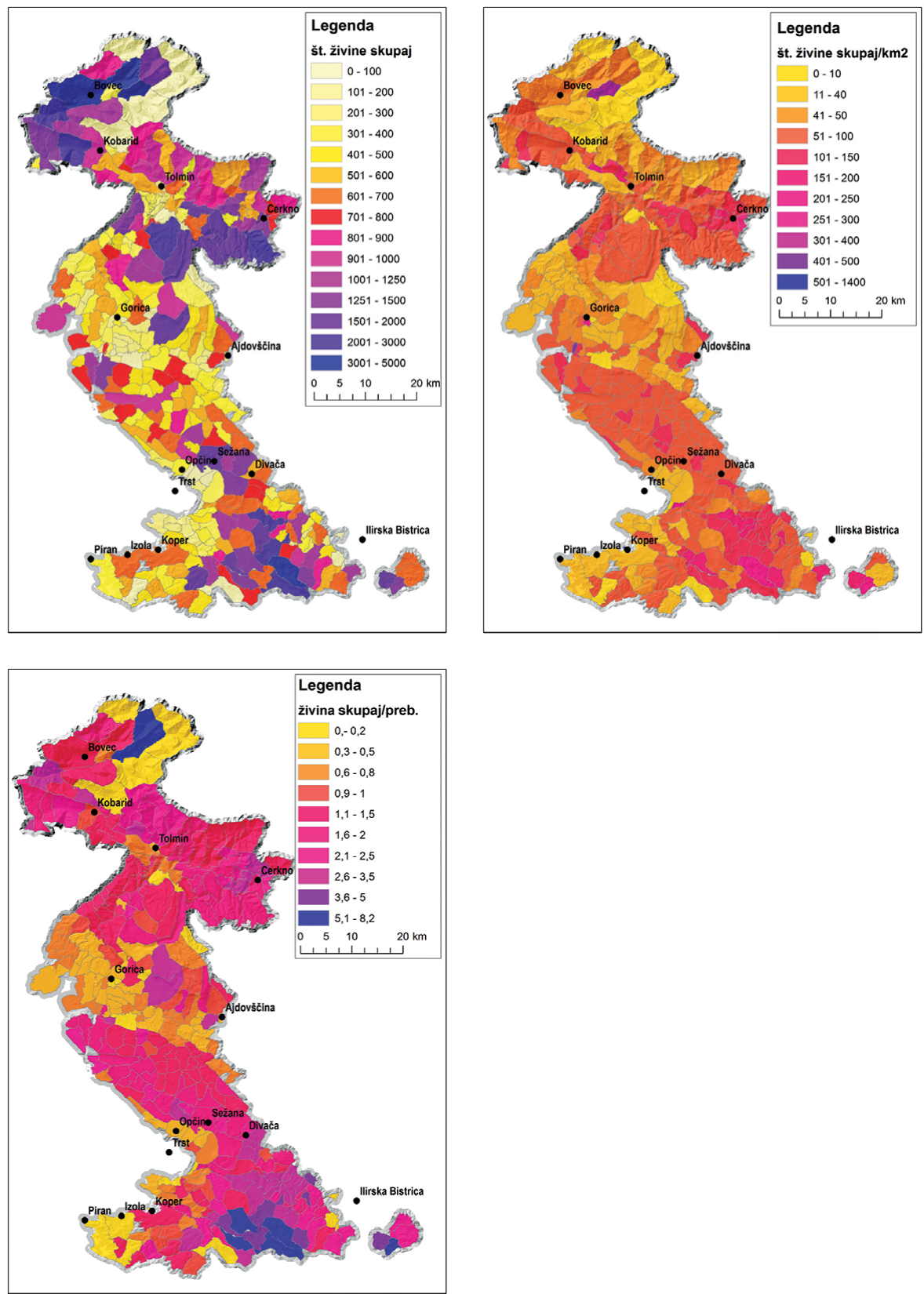

Slike II.II, II.I2 in II.I3: Število živine po k. o., gostota živine na $\mathrm{km}^{2}$ po k. o. in število živine na prebivalca po k. o. (avtorica zemljevida: Nataša Kolega, vir podlage: GURS) 

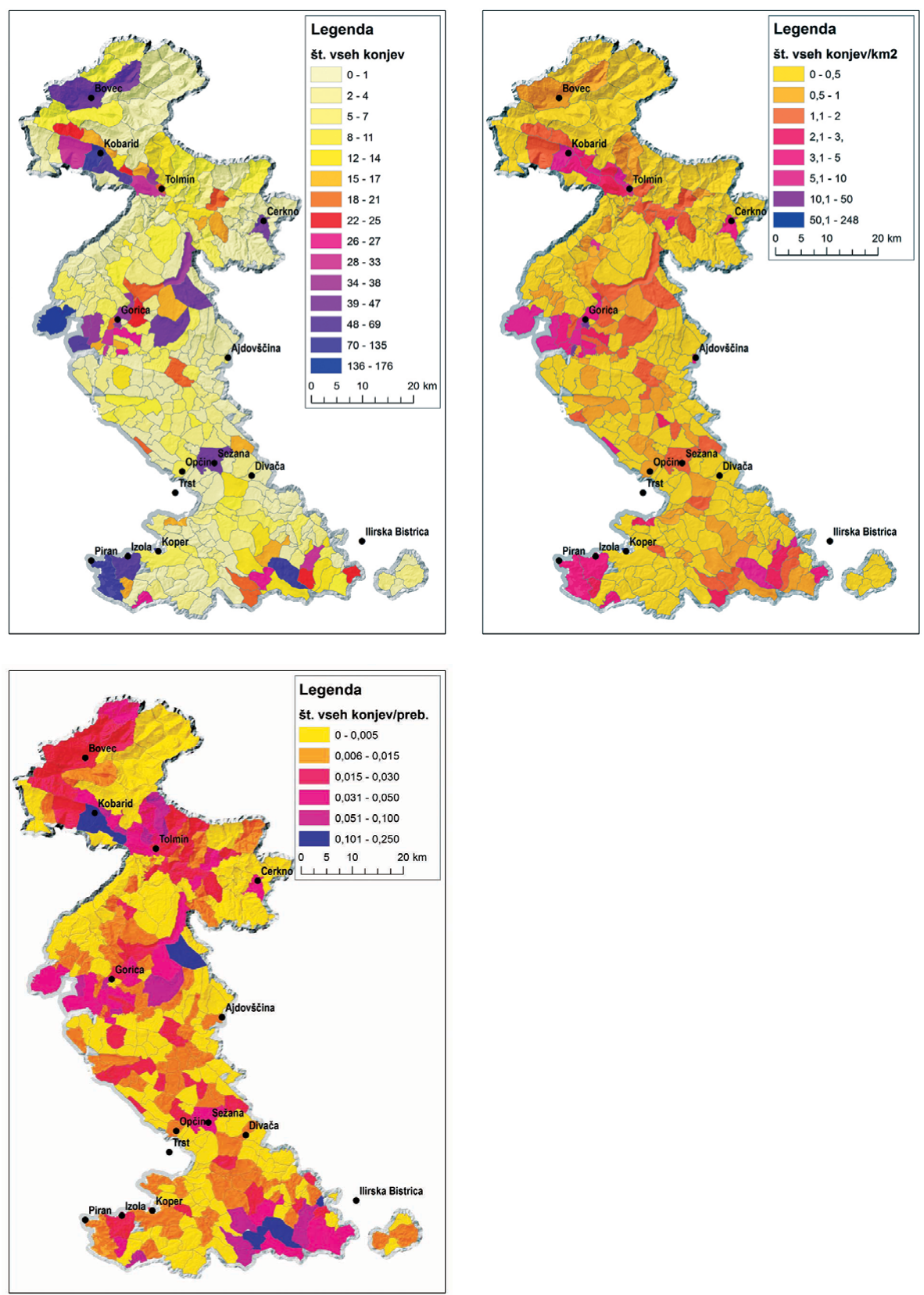

Slike II.I4, II.I5 in II.I6: Število konjev po k. o., gostota konjev na km² po k. o. in število konjev na prebivalca po k. o. (avtorica zemljevida: Nataša Kolega, vir podlage: GURS) 

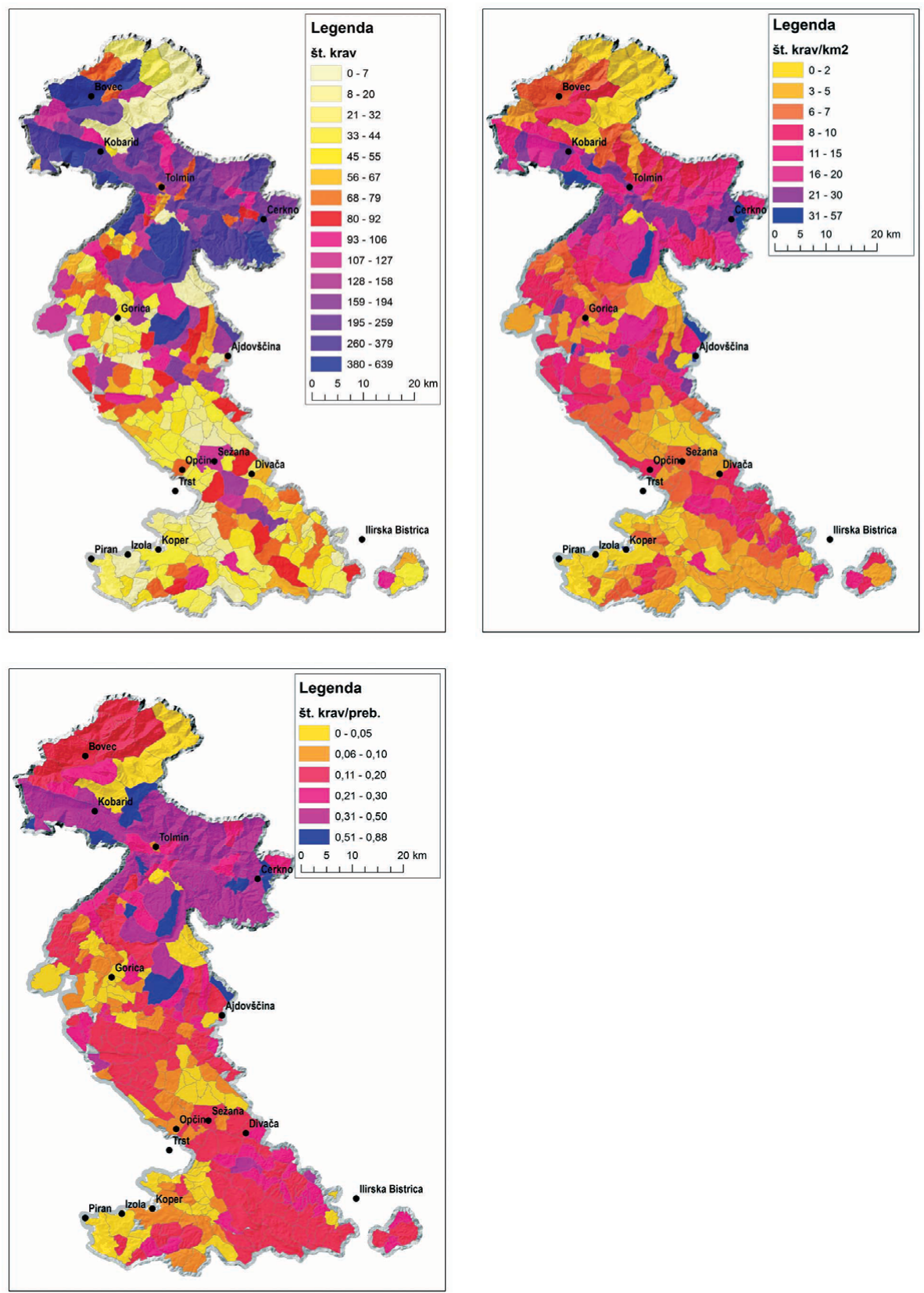

Slike II.I7, II.I8 in II.19: Število krav po k. O., gostota krav na $\mathrm{km}^{2}$ po k. o. in število krav na prebivalca po k. o. (avtorica zemljevida: Nataša Kolega, vir podlage: GURS) 

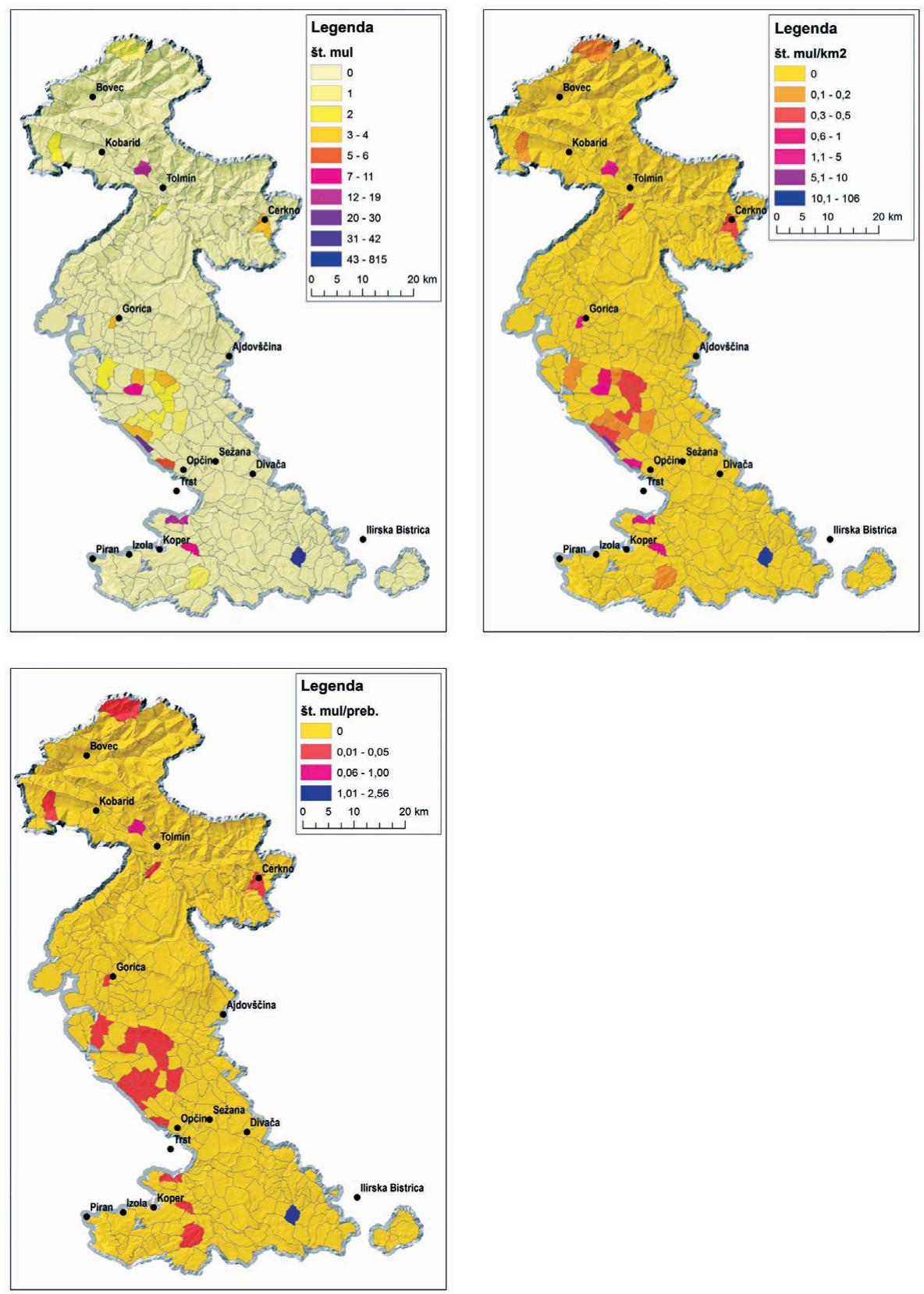

Slike II.2O, II.2I in II.22: Število mul po k. O., gostota mul na $\mathrm{km}^{2}$ po k. o. in število mul na prebivalca po k. o. (avtorica zemljevida: Nataša Kolega, vir podlage: GURS) 

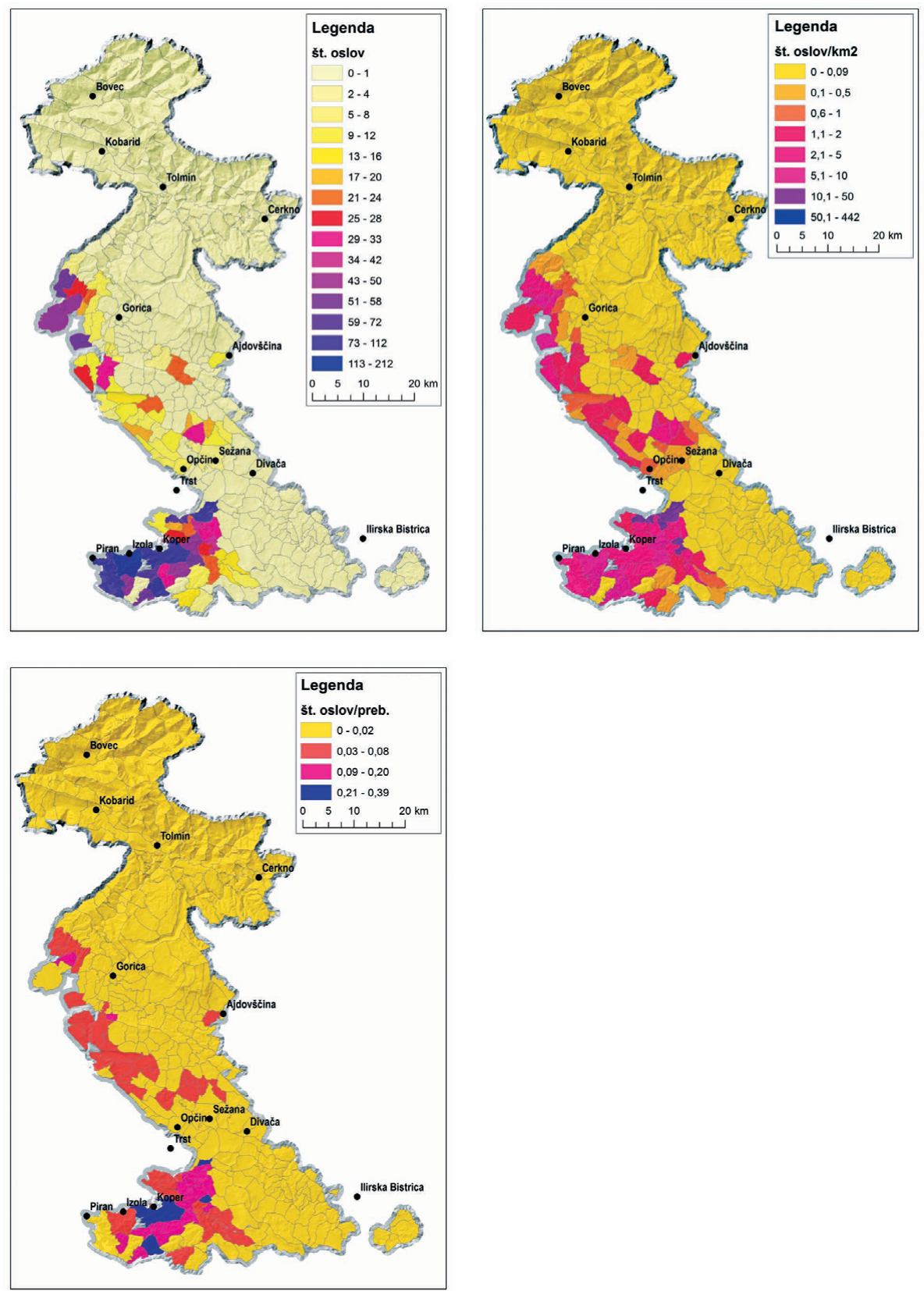

Slike II.23, II.24 in II.25: Število oslov po k. O., gostota oslov na $\mathrm{km}^{2}$ po k. o. in število oslov na prebivalca po k. o. (avtorica zemljevida: Nataša Kolega, vir podlage: GURS) 

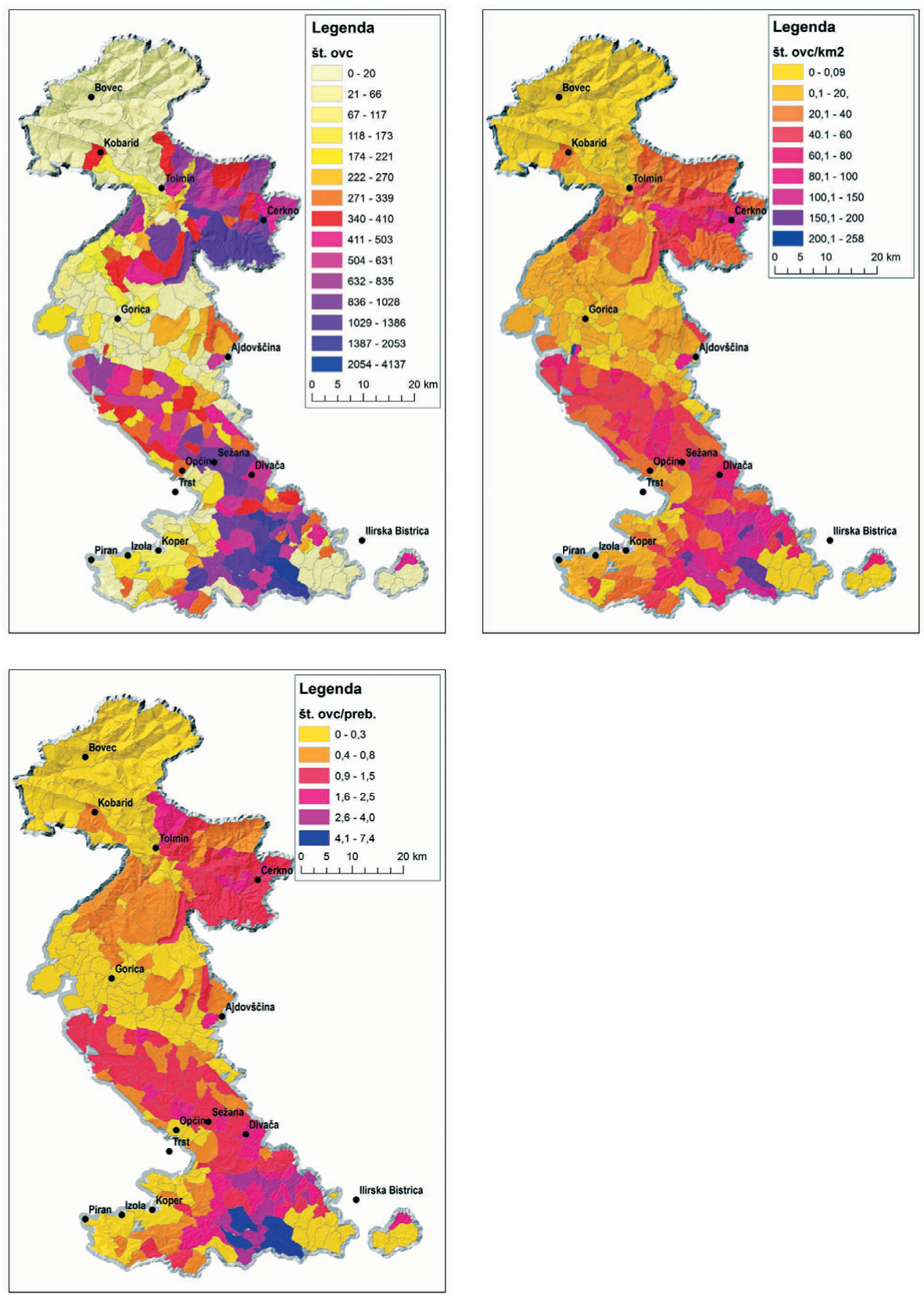

Slike II.26, II.27 in II.28: Število ovc po k. o., gostota ovc na km² po k. o. in število ovc na prebivalca po k. o. (avtorica zemljevida: Nataša Kolega, vir podlage: GURS) 

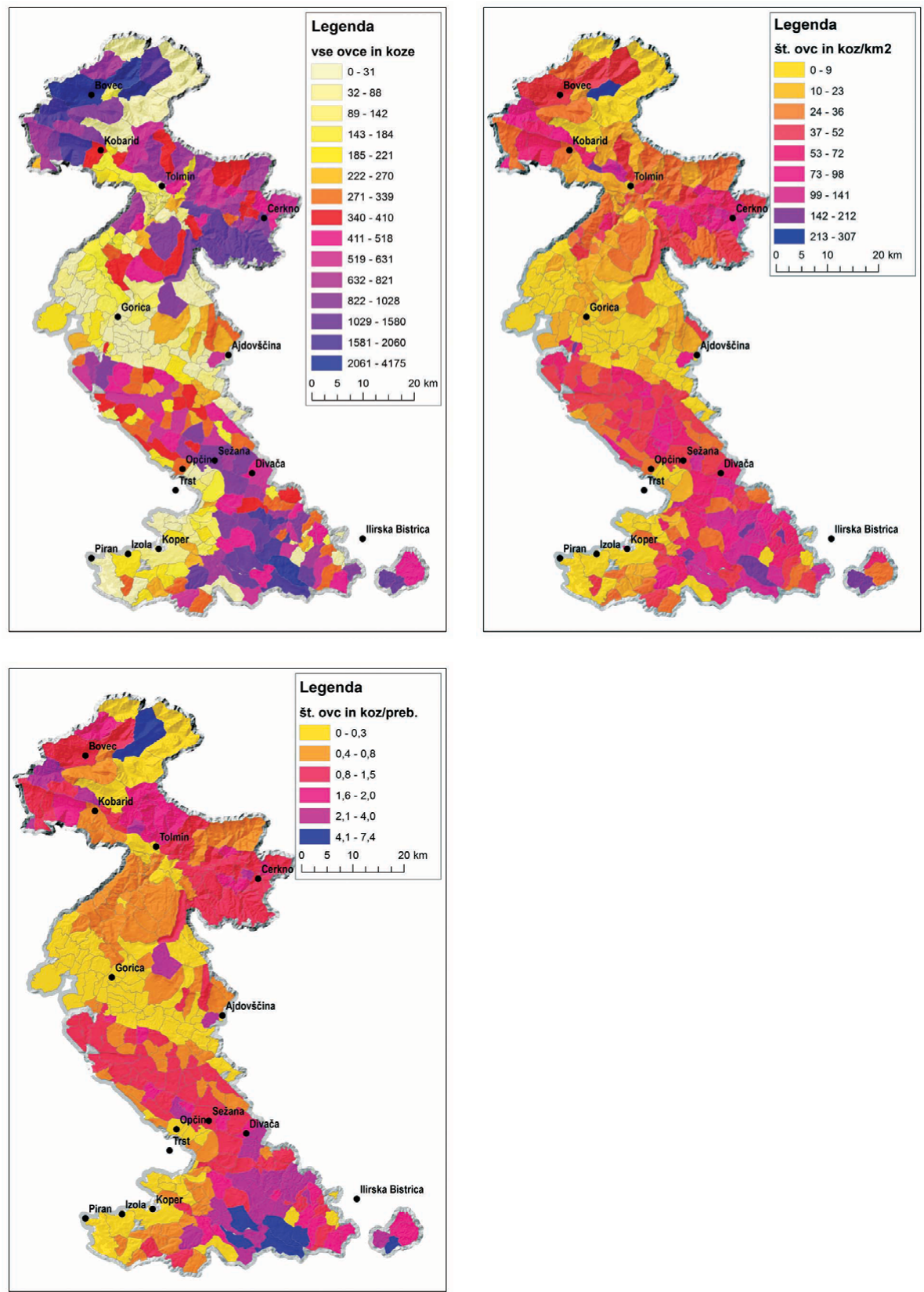

Slike II.29, II.30 in II.3I: Število ovc in koz po k. o., gostota ovc in koz na km² po k. o. in število ovc in koz na prebivalca po k. o. (avtorica zemljevida: Nataša Kolega, vir podlage: GURS) 

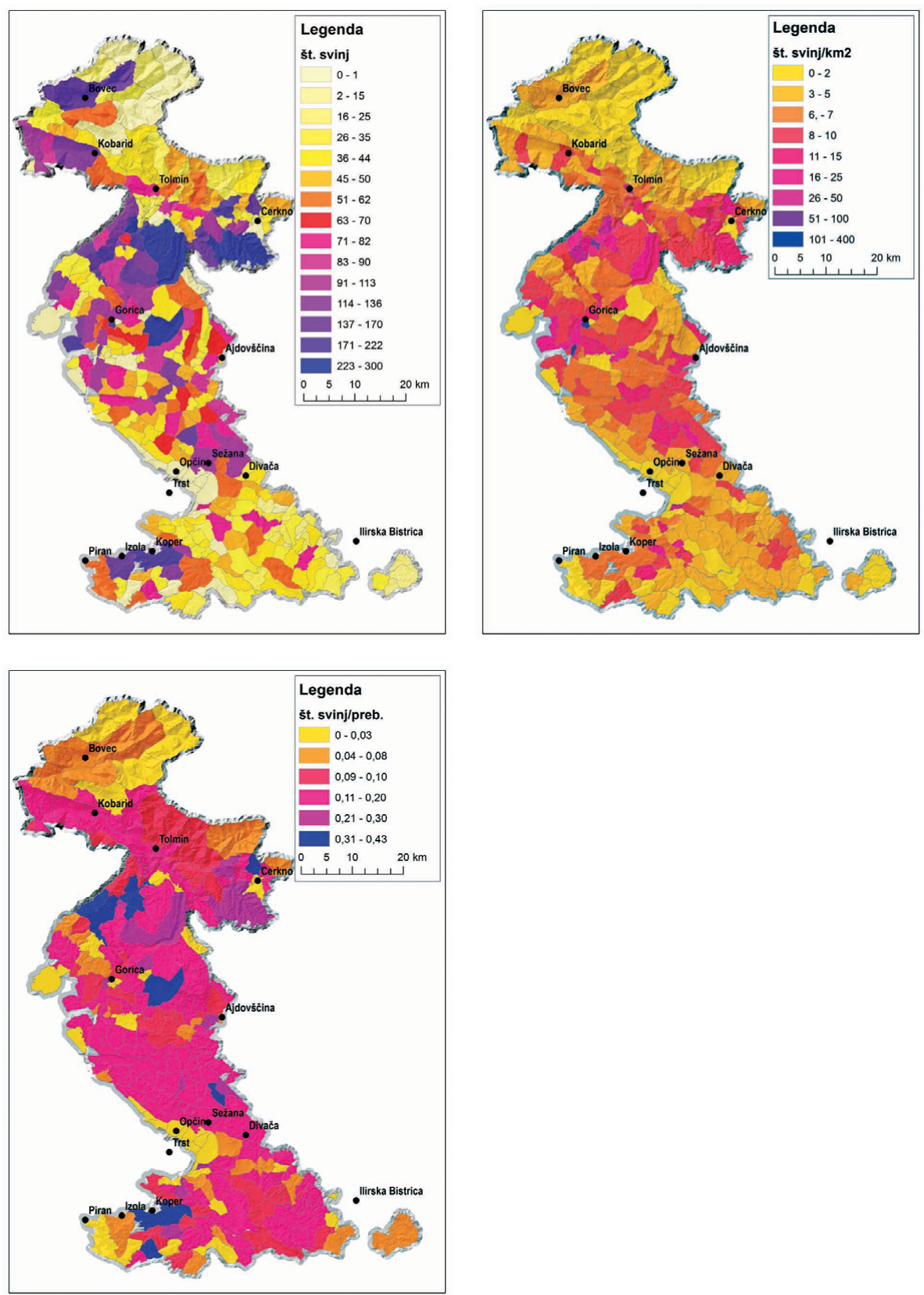

Slike II.32, II.33 in II.34: Število svinj po k. o., gostota svinj na $\mathrm{km}^{2}$ po k. o. in število svinj na prebivalca po k. o. (avtorica zemljevida: Nataša Kolega, vir podlage: GURS) 

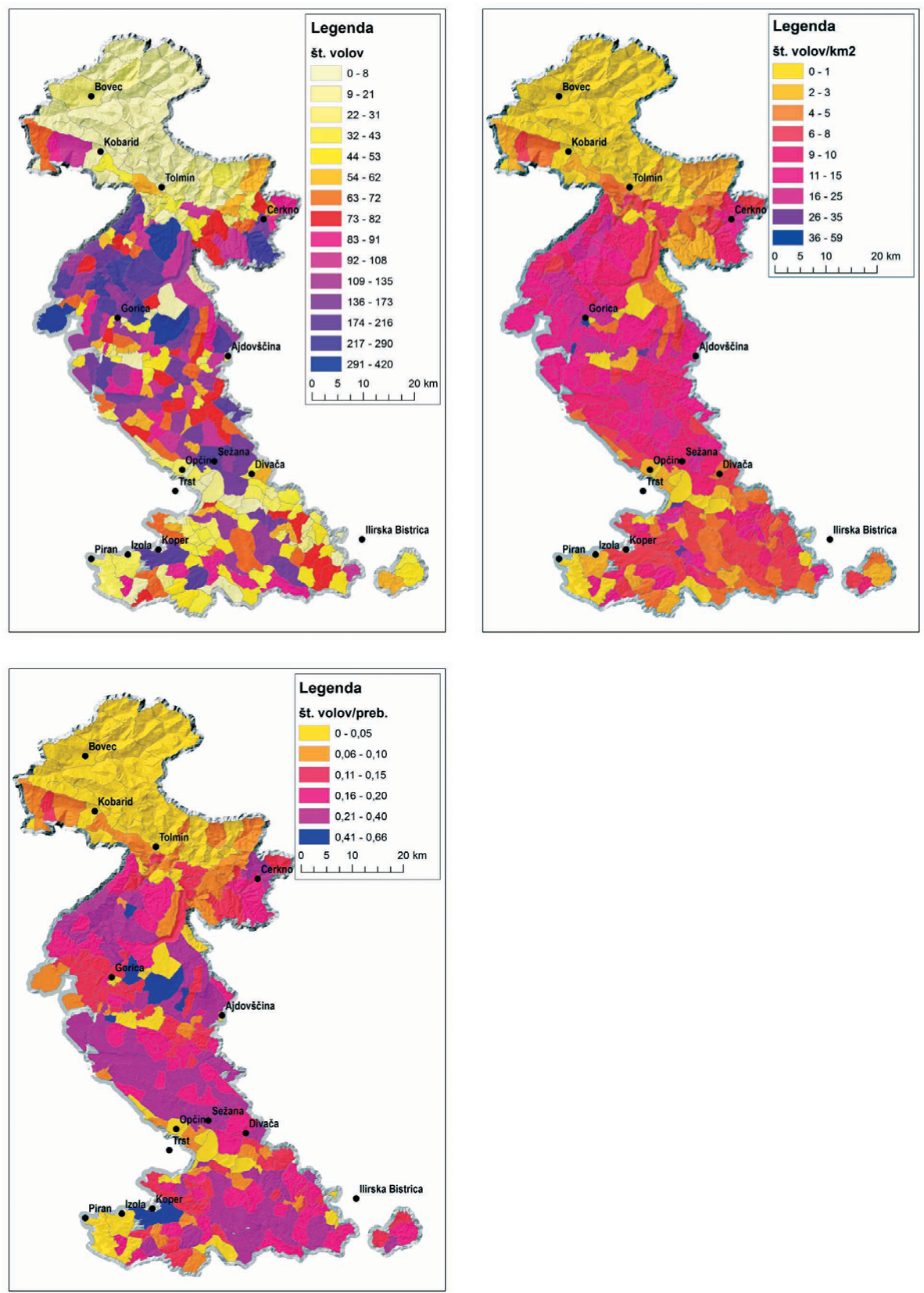

Slike II.35, II.36 in II.37: Število volov po k. o., gostota volov na $\mathrm{km}^{2}$ po k. o. in število volov na prebivalca po k. o. (avtorica zemljevida: Nataša Kolega, vir podlage: GURS) 

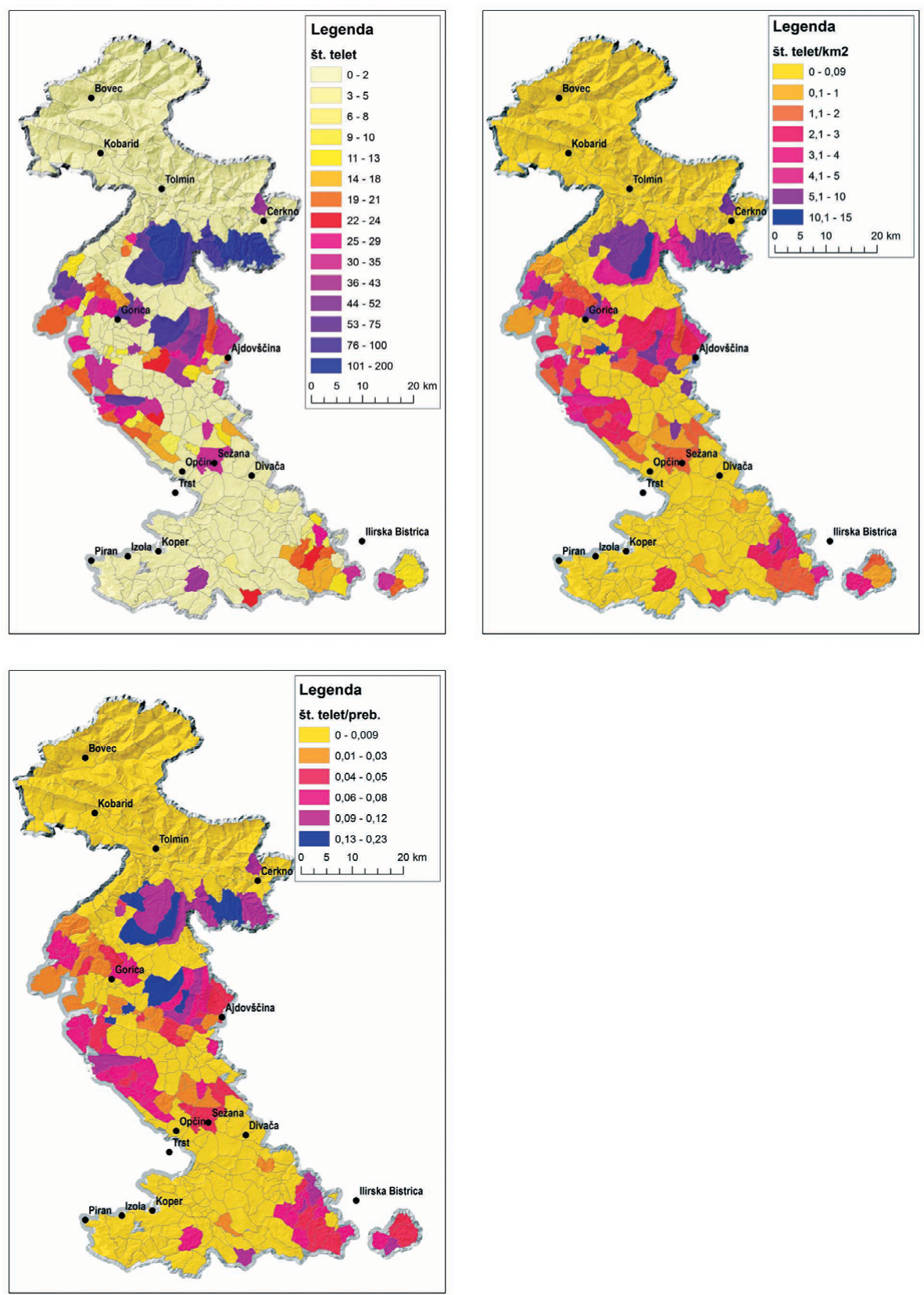

Slike II.38, II.39 in II.40: Število telet po k. o., gostota telet na km² po k. o. in število telet na prebivalca po k. o. (avtorica zemljevida: Nataša Kolega, vir podlage: GURS) 

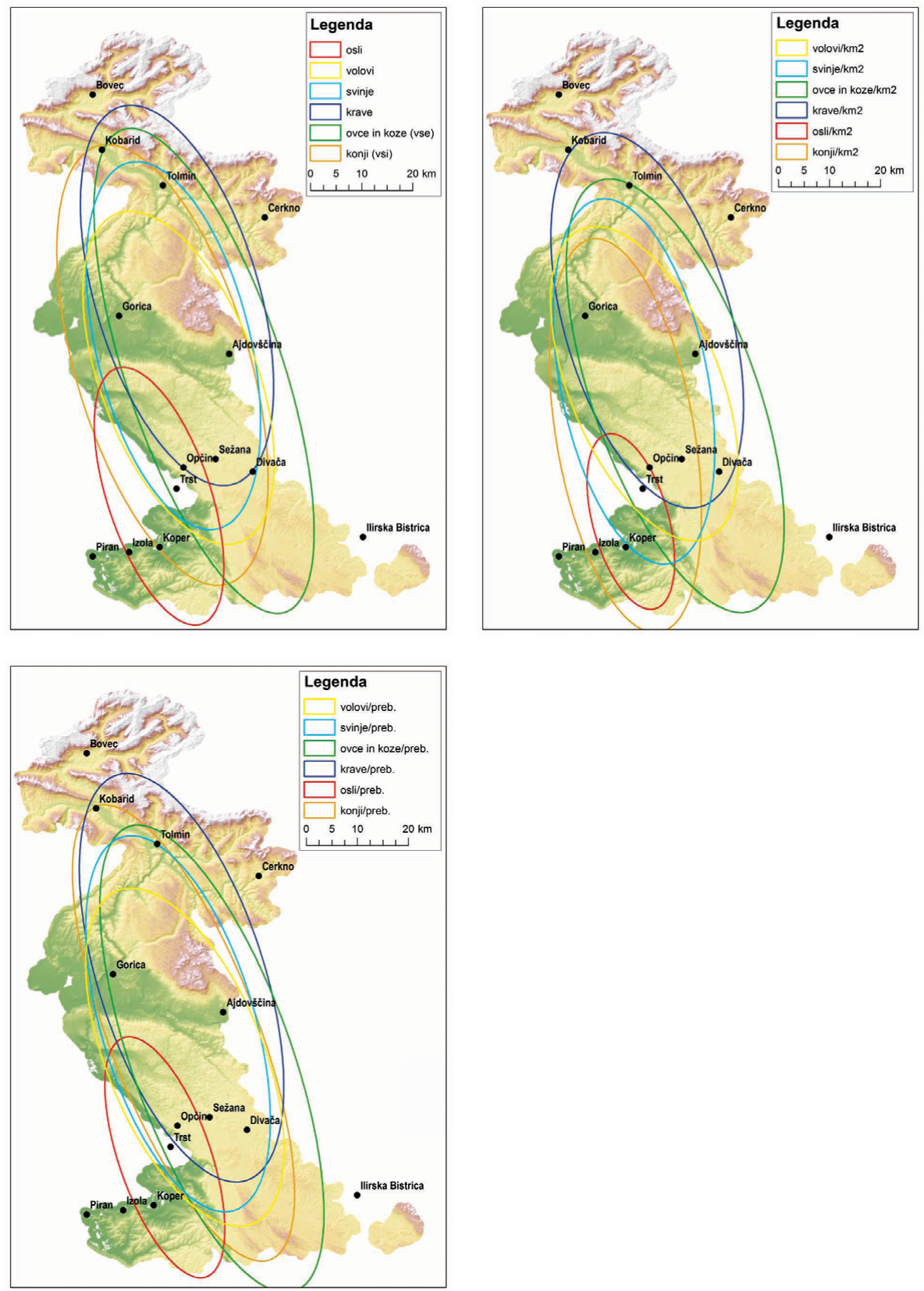

Slike II.4I, II.42 in II.43: Elipse standardne deviacije za število posameznih vrst živine po k. o., gostota posameznih vrst živine na $\mathrm{km}^{2}$ po k. o. in število posameznih vrst živine na prebivalca po k. o. (avtorica zemljevida: Nataša Kolega, vir podlage: GURS) 

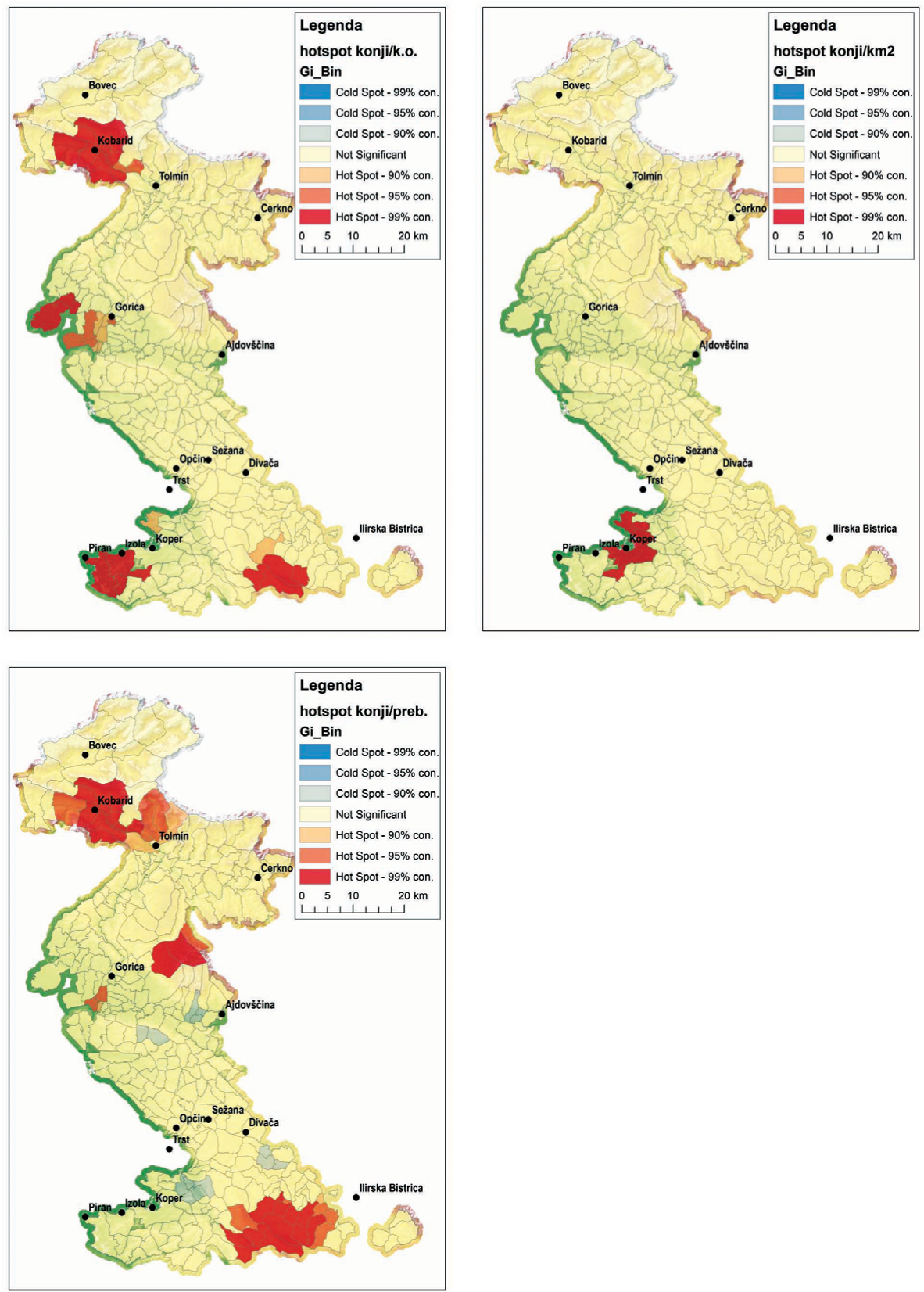

Slike II.44, II.45 in II.46: Analize vročih in hladnih točk za število konjev po k. o., število konjev na km² po k. o. in število konjev na prebivalca po k. o.

(avtorica zemljevida: Nataša Kolega, vir podlage: GURS) 

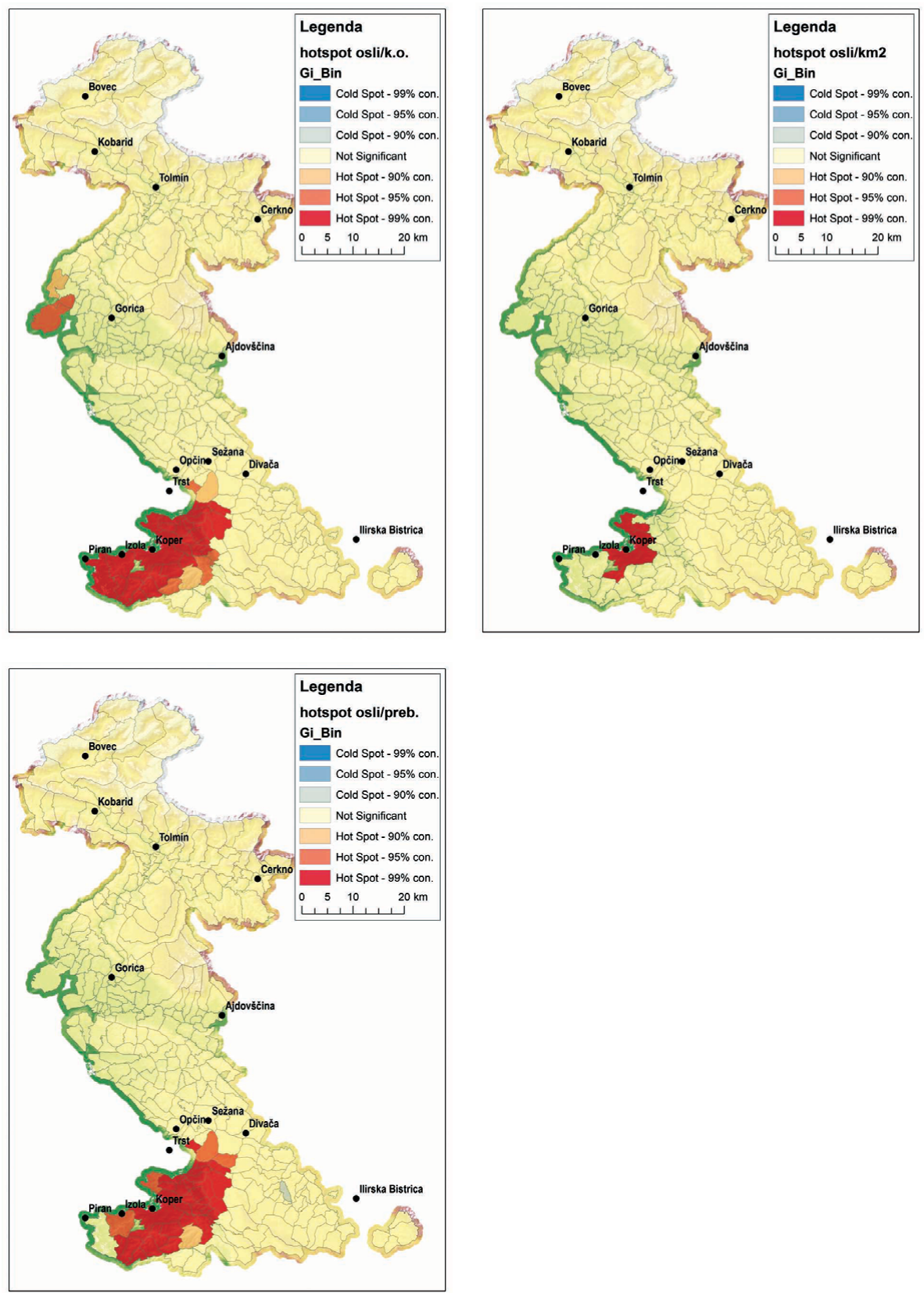

Slike II.47, II.48 in II.49: Analize vročih in hladnih točk za število oslov po k. o., gostota oslov na km² po k. o. in število oslov na prebivalca po k. o.

(avtorica zemljevida: Nataša Kolega, vir podlage: GURS) 

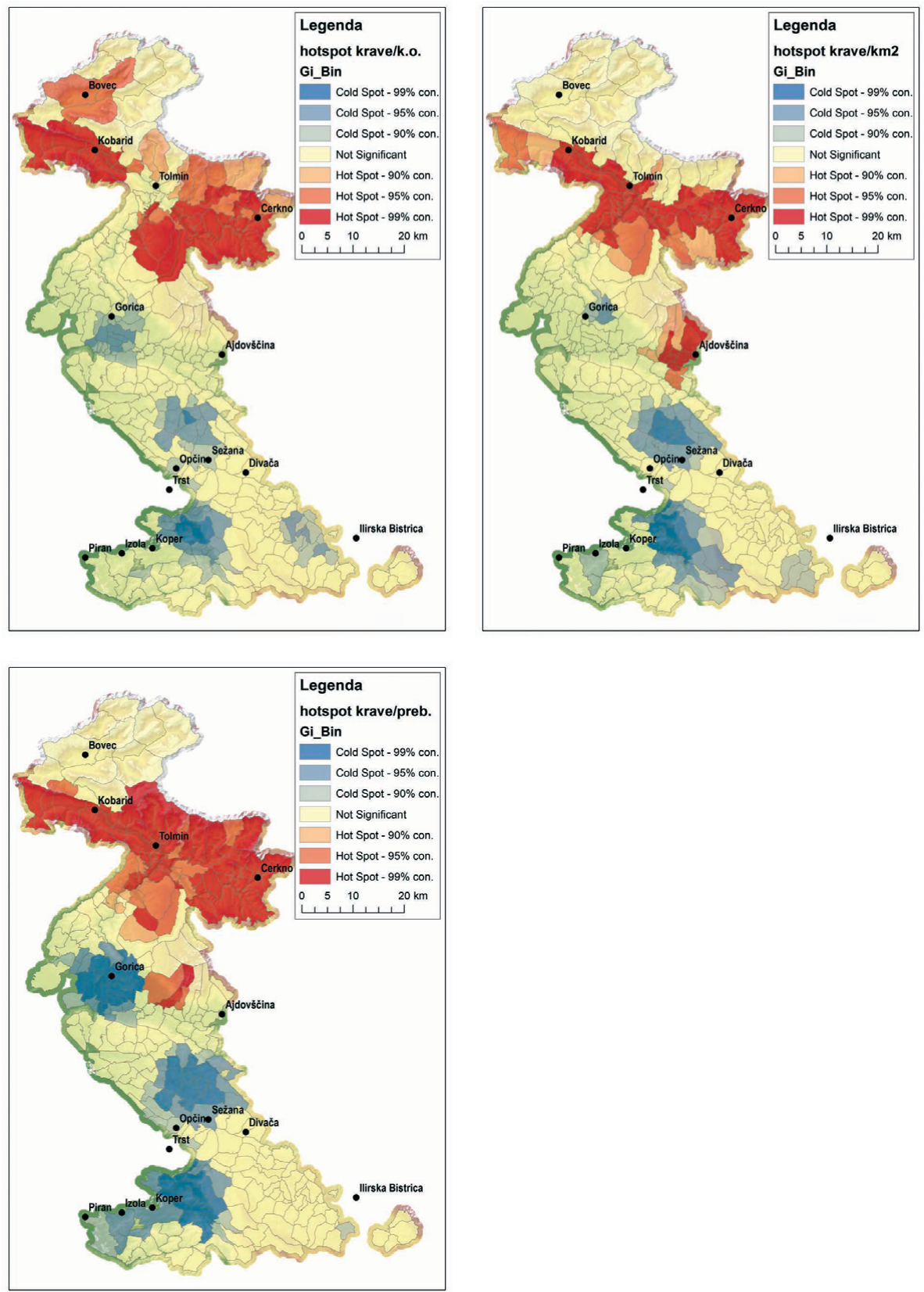

Slike II.5O, II.5I in II.52: Analize vročih in hladnih točk za število krav po k. o., gostota krav na km² po k. o. in število krav na prebivalca po k. o. (avtorica zemljevida: Nataša Kolega, vir podlage: GURS) 

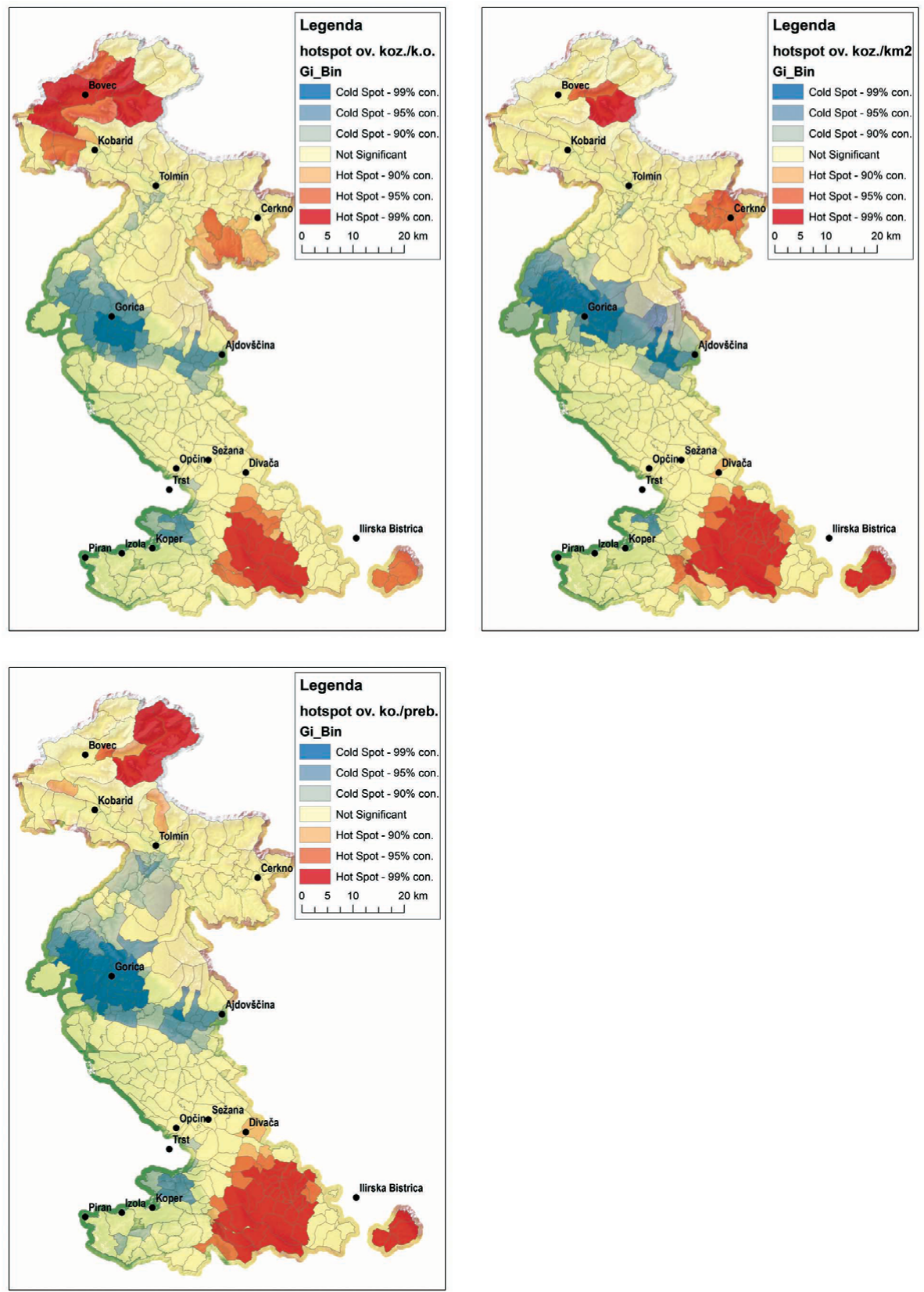

Slike II.53, II.54 in I1.55: Analize vročih in hladnih točk za število ovc in koz po k. o., gostota ovc in koz na km² po k. o. in število ovc in koz na prebivalca po k. o.

(avtorica zemljevida: Nataša Kolega, vir podlage: GURS) 

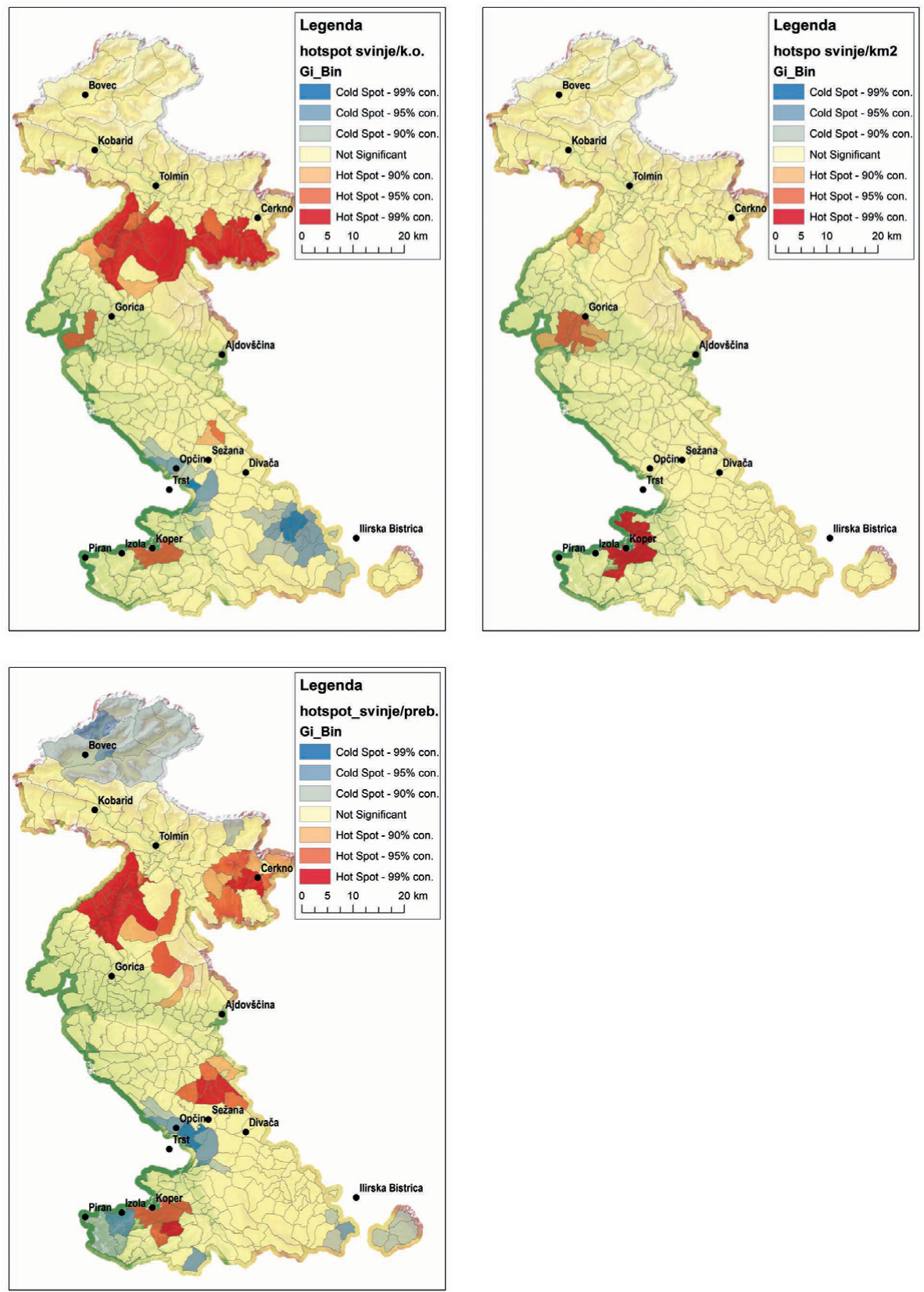

Slike II.56, II.57 in II.58: Analize vročih in hladnih točk za število svinj po k. o., gostota svinj na $\mathrm{km}^{2}$ po k. o. in število svinj na prebivalca po k. o. (avtorica zemljevida: Nataša Kolega, vir podlage: GURS) 

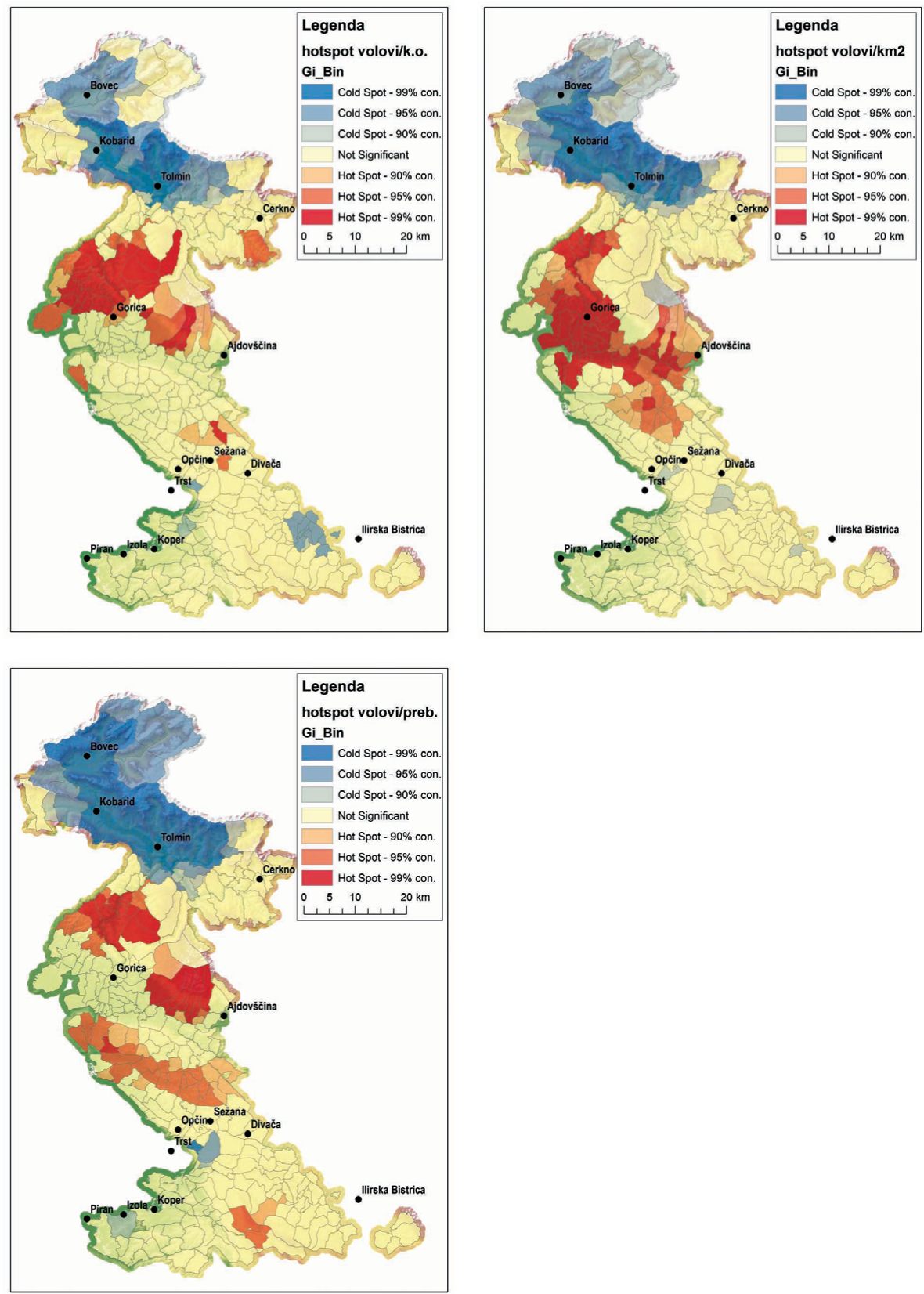

Slike II.59, II.60 in II.6r: Analize vročih in hladnih točk za število volov po k. o., število volov na km² po k. o. in število volov na prebivalca po k. o. (avtorica zemljevida: Nataša Kolega, vir podlage: GURS) 


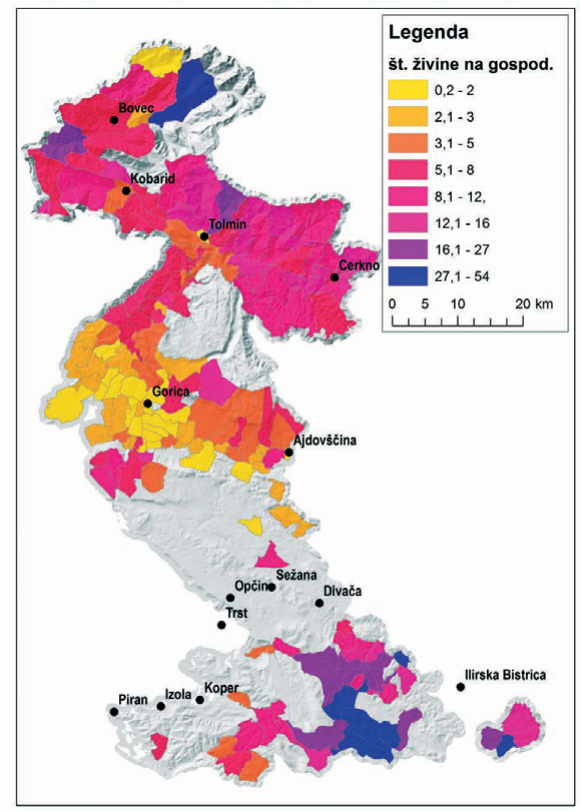

Slika Ir.62: Skupno število živine na gospodinjstvo po k. o.

\section{Viri in literatura}

Arhivski viri

ASG, C, Elaborati: Archivio di Stato di Gorizia, Catasti secc. XIX-XX, Elaborati (Catasto Franceschino)
b. 5, Biljana, S/5.17.20.21
b. 42, Mirnik, S/5.17.20.21
b. 15, Cerovo, $S / 5 \cdot 17.20 .21$
b. 45, Moš, S/5.17.20.21
b. 22, Doberdob, S/5.17.20.21
b. 40, Opatje selo, $\mathrm{S} / 5.17 .20 .21$
b. 23, Dolenje, $S / 5.17 .20 .21$
b. 49, Podgora, S/5.17.20.21
b. 24, Fara ob Soči, S/5.17.20.21
b. 51, Pevma, S/5.17.20.21
b. 29, Gabrje S/5.17.20.21
b. 61, Rupa, $S / 5 \cdot 17.20 .21$
b. 30, Gorica, $S / 5 \cdot 17.20 .21$
b. 64, Solkan, S/5.17.20.21
b. 10, Kopriva, S/5.17.20.21
b. 75, Sovodnje, S/5.17.20.21
b. $20, \mathrm{Krmin}, \mathrm{S} / 5 \cdot 17.20 .21$
b. 71, Šempeter, S/5.17.20.21
b. 36, Ločnik, S/5.17.20.21
b. 69, Šmaver, S/5.17.20.21
b. 554, Martinščina, S/5.17.20.21
b. 73, Štandrež, S/5.17.20.21
b. 39, Medana, S/5.17.20.21
b. 66, Števerjan, S/5.17.20.21 
b. $86, \mathrm{Dol} /$ Valon, $\mathrm{S} / 5 \cdot 17.20 .21$

b. 93, Vipolže, S/5.17.20.21

b. 89 , Vrtojba, S/5.17.20.21

b. 9o, Vrtojba dolenja, S/5.17.20.21

ASG, C, Mappe: Archivio di Stato di Gorizia, Catasti secc. XIX-XX, Mappe (Catasto Franceschino)

Biljana, 295- 307

Cerovo, $662-670$

Doberdob, 965 - 971

Dolenje, 1017 - 1031

Fara ob Soči, 1072 - 1086

Gabrje 1295 - 1297

Gorica, 13o7bis - 1311bis

Kopriva, $517-522$

Krmin, 898 - 925

Ločnik, 1934 - 1954

Martinščina, 2989 - 2991

Medana, 2120 - 2127

Mirnik, 2229 - 2242

Moš, $2291-2301$
Opatje selo, 2335 - 2345

Podgora, 2434 - 2441

Rupa, 2751 - 2753

Solkan, $2836-2840$

Sovodnje, 3137 - 3139

Šempeter, 3074 - 3079

Šmaver, 3036 - 3049

Štandrež, 3083 - 3086

Števerjan, 2920 - 2933

Dol/Valon, 3694 - 3701

Vipolže, $3916-3925$

Vrtojba, $3765-3767$

Vrtojba dolenja, $3772-3774$

AST, CF, Elaborati: Archivio di Stato di Trieste, Catasto Franceschino, Elaborati catastali (1818-1840)

b. 8, Ajba, S 5.17.20.21.

b. 42, Batuje, $S$ 5.17.20.21.

b. 10, Ajdovščina, S 5.17.20.21.

b. 959, Bazovica, S 5.17.20.21.

b. 20, Anhovo, S 5.17.20.21.

b. 58, Bilje, S 5.17.20.21.

b. 3o, Artviže, S 5.17.20.21.

b. 64 , Bodrež, S 5.17.20.21.

b. 14, Avber, S 5.17.20.21.

b. 952, Boljunec, S 5.17.20.21.

b. 954, Bani, S 5.17.20.21.

b. 72, Boršt (pri Kopru), S 5.17.20.21.

b. 714, Banjšice, $S$ 5.17.20.21.

b. 1039, Boršt (pri Trstu), S 5.17.20.21.

b. 38 , Barka, S 5.17.20.21.

b. 549, Bovec, $S$ 5.17.20.21.

b. 40, Bate, $S$ 5.17.20.21.

b. 46, Brdo, S 5.17.20.21. 
b. 48, Breginj, S 5.17.20.21.

b. 84 , Brestovica pri Komnu, $S$ 5.17.20.21.

b. 82, Brezovica, $\mathrm{S}$ 5.17.20.21.

b. 68 , Brje pri Komnu, S 5.17.20.21.

b. 60 , Bukovica, $S$ 5.17.20.21.

b. 536, Bukovo, S 5.17.20.21.

b. 187, Cerkno, S 5.17.20.21.

b. 183, Čadrg, S 5.17.20.21.

b. 177, Čepovan, S 5.17.20.21.

b. 164, Črnotiče, S 5.17.20.21.

b. 488, Čezsoča, S 5.17.20.21.

b. 185, Čiginj, S 5.17.20.21.

b. 692, Črni kal, S 5.17.20.21.

b. 16o, Črniče, S 5.17.20.21.

b. 251, Dane, $S$ 5.17.20.21.

b. 899, Dekani, S 5.17.20.21.

b. 253 , Deskle, S 5.17.20.21.

b. 980, Devin, S 5.17.20.21.

b. 257, Divača, S 5.17.20.21.

b. 259, Doblar, S 5.17.20.21.

b. 261, Dobravlje, S 5.17.20.21.

b. 474, Dolenji in gorenji Novaki, $S$ 5.17.20.21.

b. 1024, Dolina, S 5.17.20.21.

b. 269, Dolje, S 5.17.20.21.

b. 452, Dornberk, S 5.17.20.21.

b. 978, Draga, S 5.17.20.21.

b. 275 , Drežnica, S 5.17.20.21.

b. 277, Dutovlje, S 5.17.20.21.

b. 299, Gabrk, S 5.17.20.21.

b. 301, Gabrje ob Vipavi, S 5.17.20.21.

b. 982, Gabrovec, S 5.17.20.21. b. 303, Gabrovica pri Komnu, $S$ 5.17.20.21.

b. 327, Gojače, S 5.17.20.21.

b. 329, Golac, S 5.17.20.21.

b. 335, Gorenja vas, S 5.17.20.21.

b. 339, Gorjansko, S 5.17.20.21.

b. 337, Gorje, S 5.17.20.21.

b. 343, Gradin, S 5.17.20.21.

b. 349, Gradišče, S 5.17.20.21.

b. 347, Gradišče, S 5.17.20.21.

b. 341, Grahovo ob Bači, $S$ 5.17.20.21.

b. 311, Grgar, S 5.17.20.21.

b. 989, Gročana, S 5.17.20.21.

b. 987, Gropada, S 5.17.20.21.

b. 223, Hotična, S 5.17.20.21.

b. 231, Hrastovlje, S 5.17.20.21.

b. 999, Hribi, S 5.17.20.21.

b. 283, Hrpelje, S 5.17.20.21.

b. 239, Hruševica, S 5.17.20.21.

b. 237, Hrušica, S 5.17.20.21.

b. 247, Huje, S 5.17.20.21.

b. 359, Idrija ob Bači, S 5.17.20.21.

b. 361, Idrija pri Kanalu, $S$ 5.17.20.21.

b. 357, Idrsko, S 5.17.20.21.

b. 140, Ivanji grad, S 5.17.20.21.

b. 366, Izola, S 5.17.20.21.

b. 994, Jamlje, S 5.17.20.21.

b. 319, Javorje, $S$ 5.17.20.21.

b. 313, Jelovice, $S$ 5.17.20.21.

b. 317 , Jesenica, $S$ 5.17.20.21.

b. 102, Kal nad Kanalom, S 5.17.20.21. 
b. 106, Kamnje, S 5.17.20.21.

b. 108, Kamno, S 5.17.20.21.

b. 110, Kanal, S 5.17.20.21.

b. 102, Kanalski vrh, S 5.17.20.21.

b. 132, Kazlje, S 5.17.20.21.

b. 179, Kneža, S 5.17.20.21.

b. 116, Kobarid, S 5.17.20.21.

b. 195, Kobdilj, S 5.17.20.21.

b. 193, Kobjeglava, S 5.17.20.21.

b. 201, Komen, S 5.17.20.21.

b. 976, Kontovel, S 5.17.20.21.

b. 114, Koper, S 5.17.20.21.

b. 118, Kopriva, $S$ 5.17.20.21.

b. 205, Koritnica, S 5.17.20.21.

b. 209, Korte, S 5.17.20.21.

b. 136, Kostanjevica na Krasu, S 5.17.20.21.

b. 221, Koštabona, S 5.17.20.21.

b. 100, Kovčice, S 5.17.20.21.

b. 211, Kožana, S 5.17.20.21.

b. 213, Kozaršče, S 5.17.20.21.

b. 217 , Kozjane, $S$ 5.17.20.21.

b. 215, Kožbana, S 5.17.20.21.

b. 895 , Krajna vas, $S$ 5.17.20.21.

b. 229, Kred, S 5.17.20.21.

b. 1030, Križ (pri Trstu), S 5.17.20.21.

b. 233, Križ pri Tomaju, S 5.17.20.21.

b. 122, Krkavče, S 5.17.20.21.

b. 438, Kromberk, S 5.17.20.21.

b. 225 , Kubed, S 5.17.20.21.

b. 368 , Labinje, $S$ 5.17.20.21.

b. 370, Ladra, S 5.17.20.21.

b. 382, Lazaret, $S$ 5.17.20.21. b. 386, Ležeče, S 5.17.20.21.

b. 394, Lipa, S 5.17.20.21.

b. 416, Livek, $S$ 5.17.20.21.

b. 414, Ljubinj, S 5.17.20.21.

b. 86, Log pod Mangartom, S 5.17.20.21.

b. 410, Loka, S 5.17.20.21.

b. 400, Lokavec, $S$ 5.17.20.21.

b. 406, Loke, $S$ 5.17.20.21.

b. 203, Lokev, S 5.17.20.21.

b. 402, Lokovec, $S$ 5.17.20.21.

b. 235, Lokve, $S$ 5.17.20.21.

b. 408, Lom, S 5.17.20.21.

b. 961, Mačkolje, S 5.17.20.21.

b. 406, Male Loče, S 5.17.20.21.

b. 422, Marezige, $S$ 5.17.20.21.

b. 421, Markovščina, S 5.17.20.21.

b. 426, Materija, S 5.17.20.21.

b. 997, Mavhinje, S 5.17.20.21.

b. 428, Merče, S 5.17.20.21.

b. 1001, Milje, S 5.17.20.21.

b. 430, Modrejce, S 5.17.20.21.

b. 905, Morsko, S 5.17.20.21.

b. 706, Most na Soči, S 5.17.20.21.

b. 867, Movraž, S 5.17.20.21.

b. 950, Nabrežina, S 5.17.20.21.

b. 468, Naklo, S 5.17.20.21.

b. 227, Novokračine, S 5.17.20.21.

b. 480 , Obloke, $S$ 5.17.20.21.

b. 482, Obrov, S 5.17.20.21.

b. 484, Ocizla, S 5.17.20.21.

b. 1003, Oltra, S 5.17.20.21.

b. 1055, Opčine, S 5.17.20.21.

b. 492, Orehek, S 5.17.20.21. 
b. 597, Orehovlje, S 5.17.20.21.

b. 496, Osp, S 5.17.20.21.

b. 500, Otalež, S 5.17.20.21.

b. 271, Otlica, S 5.17.20.21.

b. 1005, Padriče, S 5.17.20.21.

b. 512, Pavlica, $S$ 5.17.20.21.

b. 516, Peč, S 5.17.20.21.

b. 514, Pečine, S 5.17.20.21.

b. 541, Piran, S 5.17.20.21.

b. 545, Planina, $S$ 5.17.20.21.

b. 547, Plave, S 5.17.20.21.

b. 1007, Plavje, S 5.17.20.21.

b. 551, Pliskovica, S 5.17.20.21.

b. 553, Podbeže, S 5.17.20.21.

b. 528, Podbrdo, S 5.17.20.21.

b. 532, Podgorje, $S$ 5.17.20.21.

b. 148, Podgrad, S 5.17.20.21.

b. 914, Podgraje, S 5.17.20.21.

b. 530, Podmelec, S 5.17.20.21.

b. 571, Podpeč, S 5.17.20.21.

b. 563, Police, $S$ 5.17.20.21.

b. 559, Poljane, $S$ 5.17.20.21.

b. 567, Poljubinj, S 5.17.20.21.

b. 510, Pomjan, $S$ 5.17.20.21.

b. 502, Ponikve, S 5.17.20.21.

b. 577, Povir, S 5.17.20.21.

b. 579, Prapetno Brdo, S 5.17.20.21.

b. 1009, Prebeneg, S 5.17.20.21.

b. 581, Pregarje, $S$ 5.17.20.21.

b. 583, Prelože, S 5.17.20.21.

b. 8o, Prešnica, S 5.17.20.21.

b. 1012, Prosek, $S$ 5.17.20.21.

b. 585, Prvačina, S 5.17.20.21. b. 601, Račice, $S$ 5.17.20.21.

b. 6, Rakitovec, $S$ 5.17.20.21.

b. 605, Ravnica, S 5.17.20.21.

b. 607, Reka - Ravne, S 5.17.20.21.

b. 603, Renče, S 5.17.20.21.

b. 1020, Repen, S 5.17.20.21.

b. 1026, Ricmanje, S 5.17.20.21.

b. 609, Rihemberk/Branik, $S$ 5.17.20.21.

b. 613, Ritomeče, S 5.17.20.21.

b. 281, Rjavče, S 5.17.20.21.

b. 617, Robidišče, S 5.17.20.21.

b. 621, Ročinj, S 5.17.20.21.

b. 619, Rodik, S 5.17.20.21.

b. 623, Rožar, S 5.17.20.21.

b. 638 , Rut, $S$ 5.17.20.21.

b. 772, Sabonje, $S$ 5.17.20.21.

b. 1022, Salež, S 5.17.20.21.

b. 744, Sedlo, S 5.17.20.21.

b. 752, Sela, S 5.17.20.21.

b. 750 , Sela na Krasu, S 5.17.20.21.

b. 748 , Selo, S 5.17.20.21.

b. 758, Sežana, S 5.17.20.21.

b. 738, Skopo, S 5.17.20.21.

b. 740, Skrilje, S 5.17.20.21.

b. 764, Slap, S 5.17.20.21.

b. 766 , Slivje, $S$ 5.17.20.21.

b. 1049, Slivno, S 5.17.20.21.

b. 768 , Smast, S 5.17.20.21.

b. 774, Soča desni breg, S 5.17.20.21.

b. 774, Soča levi breg, S 5.17.20.21.

b. 756, Srpenica, S 5.17.20.21.

b. 454 , Stara gora, S 5.17.20.21. 
b. 786, Starod, S 5.17.20.21.

b. 712, Stomaž, S 5.17.20.21.

b. 57, Strmec, S 5.17.20.21.

b. 716, Stržišče, $S$ 5.17.20.21.

b. 804, Susak, S 5.17.20.21.

b. 683 , Sv. Peter, S 5.17.20.21.

b. 8o6, Sveto, S 5.17.20.21.

b. 742, Šebrelje, S 5.17.20.21.

b. 658, Šempas, S 5.17.20.21.

b. 1028, Šempolaj, S 5.17.20.21.

b. 450 , Šentviška gora, S 5.17.20.21.

b. 12, Škofije, S 5.17.20.21.

b. 734, Škoflje, S 5.17.20.21.

b. 732, Škrbina, S 5.17.20.21.

b. 448 , Šmarje (pri Kopru), $S$ 5.17.20.21.

b. 656 , Šmarje (pri Sežani), $S$ 5.17.20.21.

b. 678, Šmartno pri Kojskem, wS 5.17.20.21.

b. 66o, Štanjel, S 5.17.20.21.

b. 664, Štjak, S 5.17.20.21.

b. 794, Štorje, S 5.17.20.21.

b. 810, Tatre, $S$ 5.17.20.21.

b. 812, Temnica, $S$ 5.17.20.21.

b. 24, Tinjan, $S$ 5.17.20.21.

b. 818 , Tolmin, $\mathrm{S}$ 5.17.20.21.

b. 822, Tomačevica, $S$ 5.17.20.21.

b. 820, Tomaj, S 5.17.20.21.

b. 823bis, Topolovec, $S$ 5.17.20.21.

b. 1051, Trebče, S 5.17.20.21.

b. 829, Trenta desni breg, $S$ 5.17.20.21. b. 829, Trenta levi breg, S 5.17.20.21.

b. 814, Trnovo, $S$ 5.17.20.21.

b. 839, Truške, $S$ 5.17.20.21.

b. 847 , Ukanje, $S$ 5.17.20.21.

b. 857, Utovlje, $S$ 5.17.20.21.

b. 871, Vareje, $S$ 5.17.20.21.

b. 877, Vatovlje, $S$ 5.17.20.21.

b. 267, Veliki Dol, S 5.17.20.21.

b. 696, Vipavski Križ, $S$ 5.17.20.21.

b. 927, Višnjevik, $S$ 5.17.20.21.

b. 929, Vodice, $S$ 5.17.20.21.

b. 1058, Voglje, $S$ 5.17.20.21.

b. 921, Vogrsko, S 5.17.20.21.

b. 931, Vojščica, S 5.17.20.21.

b. 933, Volarje, S 5.17.20.21.

b. 939, Volče, S 5.17.20.21.

b. 935, Volčji Grad, S 5.17.20.21.

b. 853, Vrsno, S 5.17.20.21.

b. 887, Vrtoče, S 5.17.20.21.

b. 887, Vrtovin, $S$ 5.17.20.21.

b. 941, Zabiče, S 5.17.20.21.

b. 943, Zajelšje, S 5.17.20.21.

b. 646, Zakriž, S 5.17.20.21.

b. 780, Zatolmin, S 5.17.20.21.

b. 726, Zazid, S 5.17.20.21.

b. 1047, Zgonik, S 5.17.20.21.

b. 642, Žabče, S 5.17.20.21.

b. 644, Žablje, S 5.17.20.21.

b. 648 , Žaga, S 5.17.20.21. 
AST, CF, Mappe: Archivio di Stato di Trieste, Catasto Franceschino, Mappe catastali (1818-1840)

Ajba, 4

Ajdovščina, 5

Anhovo, 10

Artviže, 15

Avber, 7

Bani, 652

Banjšice, 461

Barka, 24

Bate, 27

Batuje, 28

Bazovica, 654

Bilje, 39

Bodrež, 44

Boljunec, 651

Boršt (pri Kopru), 49

Boršt (pri Trstu), 687

Bovec, 353

Brdo, 30

Breginj, 33

Brestovica pri Komnu, 55

Brezovica, 54

Brje pri Komnu, 58

Bukovica, 42

Bukovo, 345

Cerkno, 122

Čadrg, 120

Čepovan, 116

Črnotiče, 447

Čezsoča, 316

Čiginj, 121,
Črni Kal, 447

Črniče, 108

Dane, 162

Dekani, 576,

Deskle, 163

Devin, 662

Divača, 165

Dobravlje, 166

Dolenji in gorenji Novaki, 309

Dolina, 681

Dolje, 170

Dornberk, 293

Draga, 661

Drežnica, 174

Dutovlje, 175

Gabrk, 190

Gabrje ob Vipavi, 191

Gabrovec, 663

Gabrovica pri Komnu, 193

Gojače, 207

Golac, 208

Gorenja vas, 211

Gorjansko, 213

Gorje, 212

Gradin, 216

Gradišče, 219

Grawdišče, 218

Grahovo ob Bači, 215

Grgar, 197

Gročana, 666

Gropada, 665 
Hotična, 143

Hrastovlje, 150

Hribi, 290

Hrpelje, 178

Hruševica, 155

Hrušica, 154

Huje, 160

Idrija ob Bači, 230

Idrija pri Kanalu, 231

Idrsko, 228

Ivanji grad, 94

Izola, 235

Jamlje, 670

Javorje, 201

Jelovice, 198

Jesenica, 200

Kal nad Kanalom, 67

Kamnje, 70

Kamno, 71

Kanal, 72

Kanalski vrh, 565

Kazlje, 90

Kneža, 118

Kobarid, 79

Kobdilj, 126

Kobjeglava, 125

Komen, 130

Kontovel, 660

Koper, 78

Kopriva, 80

Koritnica, 134

Korte, 136

Kostanjevica na Krasu, 92
Koštabona, 142

Kovčice, 66

Kozjane, 138

Kožbana, 137

Krajna vas, 574

Kred, 148

Križ (pri Trstu), 684

Križ pri Tomaju, 151

Krkavče, 82

Kromberk, 284

Kubed, 144

Labinje, 236

Ladra, 237

Lazaret, 245

Ležeče, 274

Lipa, 251

Livek, 266

Ljubinj, 265

Log pod Mangartom, 56

Loka, 260

Lokavec, 254

Loke, 256

Lokev, 132

Lokovec, 255

Lokve, 152

Lom, 258

Mačkovlje, 655

Male Loče, 256

Marezige, 271

Markovščina, 270

Materija, 276

Mavhinje, 669

Merče, 278 
Police, 363

Poljane, 360

Poljubinj, 365

Pomjan, 332

Ponikve, 327

Povir, 372

Prapetno Brdo, 373

Prebeneg, 675

Pregarje, 374

Prelože, 375

Prešnica, 53

Prosek, 676

Prvačina, 376

Račice, 389

Rakitovec, 3

Ravnica, 392

Reka - Ravne, 393

Renče, 390

Repen, 679

Ricmanje, 682

Rihemberk/Branik, 394

Ritomeče, 396

Robidišče, 398

Ročinj, 402

Rodik, 399

Rožar, 403

Rut, 412

Sabonje, 500

Salež, 680

Sedlo, 478

Sela, 480

Sela na Krasu, 481

Selo, 482
Sežana, 690

Skopo, 474

Skrilje, 476

Slap, 494

Slivje, 692

Slivno, 497

Smast, 498

Soča desni breg, 501

Soča levi breg, 501

Srpenica, 487

Stara gora, 294

Starod, 506

Stomaž, 460

Strmec, 56

Stržišče, 462

Susak, 522

Sv. Peter, 443

Sveto, 524

Šebrelje, 477

Šempas, 426

Šempolaj, 683

Šentviška gora, 292

Škofije, 6

Škoflje, 472

Škrbina, 471

Šmarje (pri Kopru), 671

Šmarje (pri Sežani), 425

Šmartno pri Kojskem, 437

Štanjel, 427

Štjak, 429

Štorje, 512

Tatre, 526

Temnica, 527 
Tinjan, 12

Tolmin, 531

Tomačevica, 533

Tomaj, 532

Topolovec, 534

Trebče, 693

Trenta desni breg, 538

Trenta levi breg, 538

Trnovo, 525

Truške, 543

Ukanje, 547

Utovlje, 553

Vareje, 561

Vatovlje, 594

Veliki Dol, 169

Vipavski Križ, 448

Višnjevik, 594

Vodice, 596
Voglje, 697

Vogrsko, 589

Vojščica, 599

Volarje, 600

Volče, 602

Volčji Grad, 604

Vrsno, 550

Vrtoče, 570

Vrtovin, 569

Zabiče, 414

Zajelšje, 608

Zakriž, 416

Zatolmin, 503

Zazid, 468

Zgonik, 691

Žabče, 606

Žablje, 415

Žaga, 417

\section{Literatura}

Arhiv Republike Slovenije 2017. »Franciscejski kataster za Kranjsko, 18231869 (Fond).« Dostop 15. avgusta 2017. http://arsq.gov.si/Query/detail. aspx?id=23253.

Čeh, M. 2002. »Analiza geodetskih podatkovnih zbirk za potrebe kmetijstva.« Doktorska disertacija, Univerza v Ljubljani.

ESRI Inc. 2008. »Natural breaks (Jenks).» Dostop 9. septembra 2017. http://webhelp.esri.com/arcgisdesktop/9.2/index. cfm?TopicName=Natural_breaks_(Jenks).

ESRI Inc. 2013. »ArcGIS 10.2.1 Help.« ArcGIS 10.2.1.

Ferlan, M. 2005. »Geodetske evidence«. Ljubljana: Fakulteta za gradbeništvo in geodezijo Univerze v Ljubljani.

Feucht, R. 2008. »Flächenangaben im österreichischen Kataster«. Diplomska naloga, Technische Universität Wien. 
Fuhrmann, S. 2007. "Digitale Historische Geobasisdaten im Bundesamt für Eich-und Vermessungswesen (BEV): Die Urmappe des Franziszeischen Kataster«. V Vermessung \& Geoinformation 1, uredil S. Klotz, 24-35. Wien: Österreichische Gesellschaft für Vermessung und Geoinformation.

Geodetska uprava Republike Slovenije 2001. »Digitalni model višin - DMV 12,5«, območje Primorske.

Geodetska uprava Republike Slovenije 2004-2015. »Državna topografska karta 1 : 50.000."

Geodetska uprava Republike Slovenije 2009. »Digitalni ortofoto posnetki, 1 : 5000, območje Primorske."

Geodetska uprava Republike Slovenije 2014. "Digitalni ortofoto posnetki, 1 : 2500, območje Primorske.»

Geodetska uprava Republike Slovenije 2016. „Državna pregledna karta 1 : 1.000.000.«

Geodetska uprava Republike Slovenije 2017. »Podatkovni sloj Katastrske občine, območje Primorske.«

Geografski inštitut Antona Melika SAZU 2016. »Podatkovni sloj mej katastrskih občin iz časa FK", delovno gradivo.

Mlakar, G. 1986. »Kataster 1, Zemljiški kataster in zemljiška knjiga.« Ljubljana: Tehniška založba Slovenije.

Ribnikar, P. 1982. »Zemljiški kataster kot vir za zgodovino. Z Zodovinski časopis 36 (4): 21-337.

Triglav, J. 2009. »Geodetsko-katastrski fondi Arhiva Republike Slovenije.« V Geodetski vestnik 53 (2): 347-361.

Verdeber, D. 2013. „Študija možnosti uporabe arhivskih gradiv Franciscejskega katastra za analizo sprememb v prostoru.« Diplomska naloga, Univerza v Ljubljani. 